\title{
Assessment of Risks and Costs Associated with Transportation of U.S. Department of Energy Radioactively Contaminated Carbon Steel
}

Environmental Assessment Division Argonne National Laboratory'

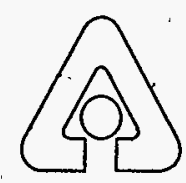

Operated by The University of Chicago, under Contract W-31-109-Eng-38, for the

United States Department of Energy 


\section{Argonne National Laboratory}

'Argonne National Laboratory, with facilities in the states of Illinois and ldaho, is owned by the United States Government, and operated by the University of Chicago under the provisions of a contract with the Department of Energy.

This technical memo is a product of Argonne's Environmental Assessment Division (EAD). For information on the division's scientific and engineering activities, contact:

Director, Environmental Assessment Division

Argonne National Laboratory

Argonne, Illinois 60439-4815

Telephone (630) 252-3107,

Presented in this technical memo are preliminary results of ongoing work or work that is more limited in scope and depth than that described in formal reports issued by the EAD.

Publishing support services were provided by Argonne's Information and Publishing Division (for more information, see IPD's home page: http://www.ipd.anl.gov/).

\section{Disclaimer}

This report was prepared as an account of work sponsored by an agency of the United States Government. Neither the United States Government nor any agency thereof, nor any of their employees, makes any warranty, express or implied, or assumes any legal liability or responsibility for the accuracy, completeness, or usefulness of any information, apparatus, product, or process disclosed, or represents that its use would not infringe privately owned rights. Reference herein to any specific commercial product, process, or service by trade name, trademark, manufacturer, or otherwise, does not necessarily constitute or imply its endorsement, recommendation, or favoring by the United States Government or any agency thereof. 'The views and opinions of authors expressed herein do not necessarily state or reflect those of the United States Government or any agency thereof.

Reproduced directly from the best available copy.

Available to DOE and DOE contractors from the Office of Scientific and Technical Information, P.O. Box 62, Oak Ridge, TN 37831; prices available from (423) 576-8401.

Available to the public from the National Technical Information Service, U.S. Department of Commerce, 5285 Port Royal Road, Springfield, VA 22161. 


\section{DISCLAIMER}

Portions of this document may be illegible in electronic image products. Images are produced from the best available original document. 


\section{Assessment of Risks and Costs Associated with Transportation of U.S. Department of Energy Radioactively Contaminated Carbon Steel}

by S.-Y. Chen, L.A. Nieves, ${ }^{\star}$ J.J. Arnish, and S.M. Folga*

Environmental Assessment Division,

Argonne National Laboratory, 9700 South Cass Avenue, Árgonne, Illinois 60439

September 1996

Work sponsored by U.S. Department of Energy, Office of Environmental Management

*Nieves and Folga are affiliated with Argonne's Decision and Information Sciences Division. 


\section{CONTENTS}

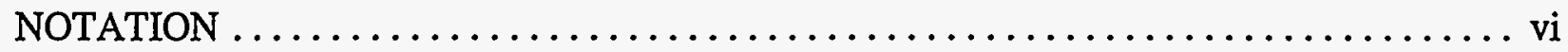

SUMMARY $\ldots \ldots \ldots \ldots \ldots \ldots \ldots \ldots \ldots \ldots \ldots \ldots \ldots \ldots \ldots \ldots \ldots \ldots \ldots \ldots \ldots \ldots$

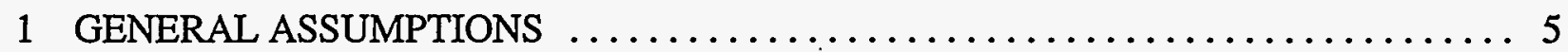

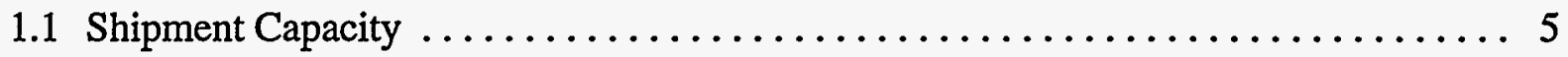

1.2 Loading Characteristics of Radioactively Contaminated Carbon

Steel Products ..................................... 5

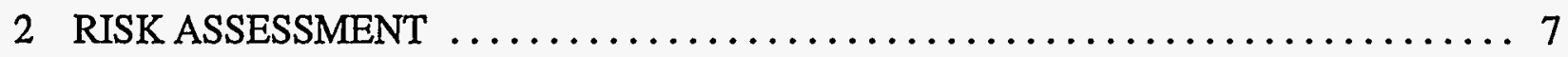

2.1 Radiological Characteristics .............................. 7

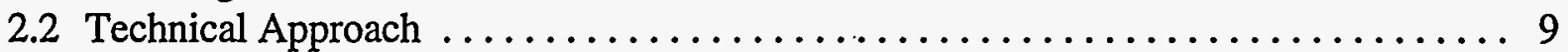

2.3 Calculation of Unit-Risk Factors $\ldots \ldots \ldots \ldots \ldots \ldots \ldots \ldots \ldots \ldots \ldots \ldots \ldots \ldots \ldots \ldots \ldots \ldots$

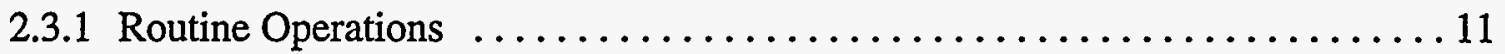

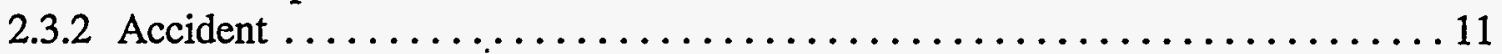

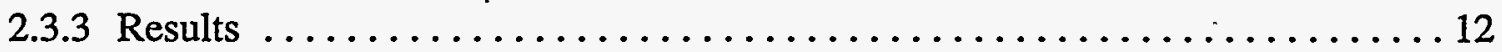

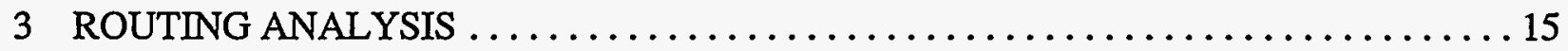

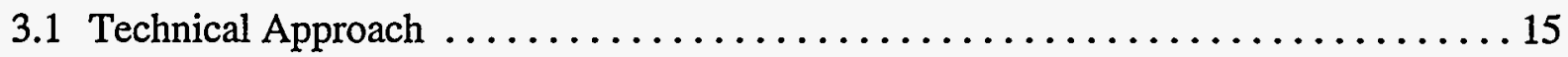

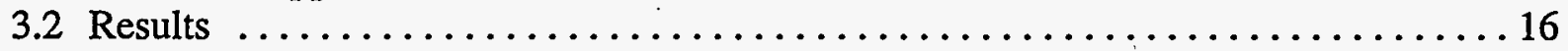

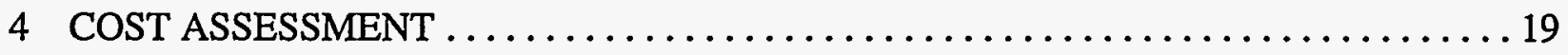

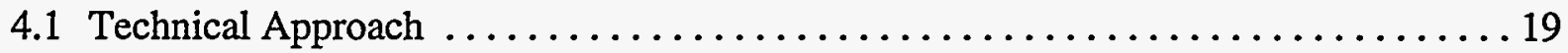

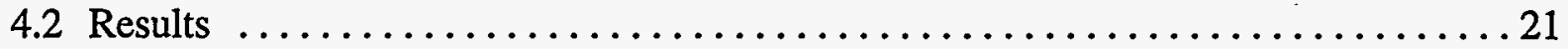

5 APPLICATION TO OPTIONS: AN EXAMPLE $\ldots \ldots \ldots \ldots \ldots \ldots \ldots \ldots \ldots \ldots$

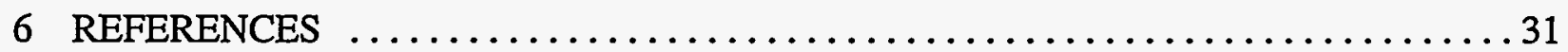

APPENDIX A: RADIOLOGICAL PROFILE OF RADIOACTIVE SCRAP METALS AT DOE FUEL CYCLE FACILITIES . . . . . . . . . . . . . . . 33

APPENDIX B: RADIONUCLIDE PARTITIONING FACTORS IN THERMAL/ MELT REFINING OF STEEL $\ldots \ldots \ldots \ldots \ldots \ldots \ldots \ldots \ldots \ldots \ldots . \ldots 1$ 


\section{TABLES}

1 Fixed and Variable Unit Costs by Cargo Type, Container Type, and Transport Mode

2 Cargo Characteristics and Shipment Loading Assumptions for Radioactively

Contaminated Carbon Steel

3 Assumed RCCS Activity Levels or Dose Rates by Cargo Type $\ldots \ldots \ldots \ldots \ldots \ldots$

4 Unit-Risk Factors for RCCS and Associated Materials ................... 13

5 Highway and Railway Mileages between Origin and Processing Sites

for the Centralized and Two-Regional-Site Scenarios $\ldots \ldots \ldots \ldots \ldots \ldots \ldots \ldots \ldots$

6 Mileages between RCCS Origin, Processing, and Disposal Sites

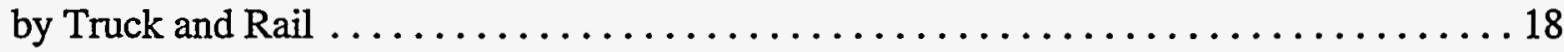

7 Unit Costs for RCCS Shipment as a Function of RCCS Cargo, Container Type, and Transport Mode

8 RCCS Inventory and Shipment Estimates by Site, Cargo Type, and Shipment Mode

9 Risk Estimate Components for RCCS Shipments for Option Scenarios Involving

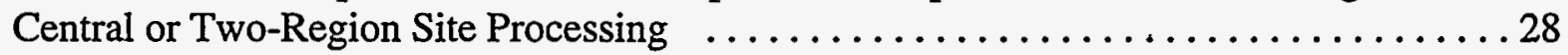

10 Risk and Mileage Summary for RCCS Policy Option Scenarios $\ldots \ldots \ldots \ldots \ldots$

A.1 Activity Profile for Scrap Metal from a Uranium Enrichment Facility ............ 34

A.2 Activity Profile for Scrap Metal from a Uranium Manufacturing Facility $\ldots \ldots \ldots \ldots 35$

A.3 Activity Profile for Scrap Metal from a Plutonium Manufacturing Facility $\ldots \ldots \ldots \ldots 36$

A.4 Activity Profile for Scrap Metal from a Tritium Production Facility $\ldots \ldots \ldots \ldots . \ldots 36$

A.5 Activity Profile for Piping from a Light-Water Reactor $\ldots \ldots \ldots \ldots \ldots \ldots \ldots \ldots$

A.6 Activity Profile for a Fuel Reprocessing Facility $\ldots \ldots \ldots \ldots \ldots \ldots \ldots \ldots \ldots \ldots$

A.7 Activity Profile for Naturally Occurring Radioactive Material $\ldots \ldots \ldots \ldots \ldots \ldots . \ldots 38$

B.1 Radionuclide Partitioning Factors for Carbon Steel $\ldots \ldots \ldots \ldots \ldots \ldots \ldots \ldots \ldots$ 


\section{FIGURES}

1 Flow Diagram for Transportation Risk $\ldots \ldots \ldots \ldots \ldots \ldots \ldots \ldots \ldots \ldots \ldots \ldots \ldots \ldots \ldots \ldots \ldots$

2 Components of Total Health Detriment from Truck Transportation $\ldots \ldots \ldots \ldots \ldots$

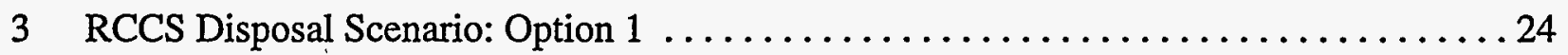

4 Scenarios for Ingot Processing and Disposal: Option $2 \ldots \ldots \ldots \ldots \ldots \ldots \ldots \ldots \ldots \ldots \ldots \ldots \ldots$

5 Scenarios for Container Production: Option $3 \ldots \ldots \ldots \ldots \ldots \ldots \ldots \ldots \ldots \ldots \ldots \ldots \ldots \ldots$

6 Response of Total Mileage to Number of Processing Sites $\ldots \ldots \ldots \ldots \ldots \ldots \ldots$ 


\section{NOTATION}

The following is a list of the acronyms, initialisms, and abbreviations (including units of measure) used in this document. Acronyms used only in tables are defined in the respective tables.

\section{ACRONYMS, INITIALISMS, AND ABBREVIATIONS}

CFR Code of Federal Regulations

DOE U.S. Department of Energy

FEMP Fernald Environmental Management Project

ORGDP Oak Ridge Gaseous Diffusion Plant

RCCS radioactively contaminated carbon steel

WM PEIS Waste Management Programmatic Environmental Impact Statement

\section{ELEMENTS AND CHEMICALS}

$\begin{array}{llll}\mathrm{Am} & \text { americium } & \mathrm{Ni} & \text { nickel } \\ \mathrm{C} & \text { carbon } & \mathrm{Np} & \text { neptunium } \\ \mathrm{Cm} & \text { curium } & \mathrm{Pb} & \text { lead } \\ \mathrm{Co} & \text { cobalt } & \mathrm{Po} & \text { polonium } \\ \mathrm{Cs} & \text { cesium } & \mathrm{Pu} & \text { plutonium } \\ \mathrm{Eu} & \text { europium } & \mathrm{Ra} & \text { radium } \\ \mathrm{Fe} & \text { iron } & \mathrm{Sr} & \text { strontium } \\ \mathrm{H} & \text { hydrogen } & \mathrm{Tc} & \text { technetium } \\ \mathrm{I} & \text { iodine } & \mathrm{Th} & \text { thorium } \\ \mathrm{Mn} & \text { manganese } & \mathrm{U} & \text { uranium } \\ \mathrm{Nb} & \text { niobium } & \mathrm{UF}_{6} & \text { uranium hexafluoride }\end{array}$

\section{UNITS OF MEASURE}

$\begin{array}{llll}\mathrm{Bq} & \text { becquerel(s) } & \mathrm{m} & \text { meter(s) } \\ \mathrm{cm}^{2} & \text { square centimeter(s) } & \mathrm{mi} & \text { mile(s) } \\ \mathrm{ft} & \text { foot (feet) } & \mathrm{mrem} & \text { millirem } \\ \mathrm{ft}^{3} & \text { cubic foot (feet) } & \mathrm{nCi} & \text { nanocurie(s) } \\ \mathrm{g} & \text { gram(s) } & \mathrm{pCi} & \text { picocurie(s) } \\ \mathrm{h} & \text { hour(s) } & \mathrm{ppb} & \text { part(s) per billion } \\ \mathrm{kg} & \text { kilogram(s) } & \mathrm{ppm} & \text { part(s) per million } \\ \mathrm{lb} & \text { pound(s) } & \mathrm{yr} & \text { year(s) }\end{array}$




\title{
ASSESSMENT OF RISKS AND COSTS ASSOCIATED WITH TRANSPORTATION OF U.S. DEPARTMENT OF ENERGY RADIOACTIVELY CONTAMINATED CARBON STEEL
}

\author{
by \\ S.-Y. Chen, L.A. Nieves, J.J. Arnish, and S.M. Folga
}

\section{SUMMARY}

This report provides a preliminary assessment of potential human health risks and develops unit risks and costs for transporting radioactively contaminated carbon steel (RCCS) scrap between U.S. Department of Energy (DOE) sites. The RCCS would be generated from DOE activities (current or future) and from decontamination and decommissioning of DOE facilities. The estimates of transportation system risk reflect preliminary information regarding the quantities of RCCS at some sites and the spectrum of activity in RCCS at various types of DOE facilities.

The DOE policy options developed under the DOE "Recycle 2000" initiative ${ }^{1}$ and considered in this risk assessment are as follows:

- Option 1 - continuing RCCS disposal operations as currently practiced,

- Option 2-processing RCCS into ingots (volume-reduced form) for disposal, and

- Option 3-processing RCCS into disposal containers for one-time use within the Environmental Management program.

For options 2 and 3, conceptual system-configuration alternatives for processing RCCS at two regional sites or one national site are also evaluated. Risks and costs of transportation would be associated with shipping the RCCS, its products (i.e., ingots or waste containers), and secondary wastes. Specifically, this assessment considers truck or rail transportation of (1) purchased containers to scrap-originating sites, (2) RCCS in boxes to disposal sites, (3) RCCS for processing into ingots or for fabrication into containers, (4) RCCS ingots to disposal sites, (5) containers fabricated from RCCS to user sites, and (6) secondary waste to disposal sites. Costs and risks of using RCCSfabricated containers to dispose of program wastes are not specifically assessed because they would be the same as for disposal of program wastes in purchased (non-RCCS) containers. All transportation is assumed to occur by truck and rail services that are available commercially.

1 U.S. Department of Energy, 1994, Recycle Policy Workshop, Denver, Colo., Dec. 6-8. 
Given the current stage of DOE decommissioning operations, the information currently available does not permit a full-scale analysis of transportation risks. Complete information on the RCCS inventory (physical quantity and activity) for each major DOE site is not available; data on scrap inventories have only been compiled for a limited number of sites, ${ }^{2}$ and no estimates of future scrap generation exist. Determining the number of shipments required and the associated risk totals for the DOE's alternatives is not possible without extensive inventory estimates. Therefore, the current analysis is limited to providing unit-risk and cost data elements. A sample calculation of system risk is provided by using the currently available information on RCCS inventory to illustrate the application of the derived unit-risk data to two conceptual processing systems. Transportation costs are calculated separately, by using the unit-cost factors, as part of the Economic Cost Model and are presented in a separate study. ${ }^{3}$

The risk assessment methodology used in this report is consistent with that ${ }^{4}$ developed for the DOE Waste Management Programmatic Environmental Impact Statement analysis. Transportation risk is composed of (1) latent (fatal or total) cancer risks resulting primarily from exposure to radiation from RCCS or its products but also resulting from vehicle exhaust emissions and (2) potential traffic accident fatality or injury risks from nonradiological causes. In general, because of the low radiation levels associated with RCCS and its products, the nonradiological risk, primarily from traffic accidents, dominates the overall transportation risks associated with RCCS shipment.

Risks from shipping the empty fabricated containers are generally lower than for unprocessed RCCS because of the potential removal of radioactivity by the metal melting process. Loading density and shipment configuration also affect the risk factors. Higher risk factors are estimated for the secondary wastes because of the activity concentration. On the basis of information regarding the urban, suburban, and rural distribution of routes, the unit-risk factors are 4.3 to $4.8 \times 10^{-8}$ fatalities per truck-mile and 4.9 to $5.2 \times 10^{-8}$ fatalities per railcar-mile for RCCS, ingot, or fabricated box transport. More than $90 \%$ of these risks are from nonradiological causes. For empty purchased (non-RCCS) containers, the unit-risk factors are $3.9 \times 10^{-8}$ per truck-mile and $4.8 \times 10^{-8}$ per rail-mile. The comparable figures for secondary waste transportation are $6.9 \times 10^{-8}$ and $5.6 \times 10^{-8}$, respectively. The somewhat higher radiation levels assumed for secondary waste contribute to higher risk factors than those for unprocessed RCCS. For traffic accidents, risk factors that include injuries are at least a factor of 10 higher than those for fatalities alone, and those for train

2 U.S. Department of Energy, 1995, Operable Unit 3 Remedial Action Cost Estimate, Sections 1-3 and Appendixes A-C, Fernald Field Office, Fernald, Ohio.

3 Warren, S., et al., 1995, Cost Model for DOE Radioactively Contaminated Carbon Steel Recycling, U.S. Department of Energy, Office of Environmental Management, Washington, D.C.

4 Chen, S.-Y., et al., 1995, “Assessment of Transportation Risk for the U.S. Department of Energy Environmental Management Programmatic Environmental Impact Statement," presented at WM '95 Conference, Tucson, Ariz., sponsored by the U.S. Department of Energy, March. 
transport are substantially higher than those for truck transport. Risk factors that include total cancer incidence and severe genetic effects are about $50 \%$ higher than those for latent fatalities alone.

This assessment provides fixed and variable unit costs (dollars per shipment-mile). Fixed and variable costs vary by transport mode (truck or rail), by distance traveled, and by the form of the RCCS (scrap, ingots, fabricated containers, or secondary wastes). In practice, the costs may be affected by the number of shipments and the time covered by the contract. Either truck or rail transportation may have lower variable costs, depending on the dimensions and weight of the material being hauled and the shipping distance. Ranges of fixed and variable costs per shipment are shown in Table 1. Higher costs are assumed for secondary waste transportation because of greater handling and certification costs for this material. In general, variable costs decline as shipping distance increases, and variable costs are higher per ton for fabricated containers (empty) than for scrap haulage.

A calculation is performed to compare the system options for RCCS processing by using the unit-risk factors. Four processing system scenarios are presented that use the currently available RCCS inventory data. ${ }^{5}$ One system is centralized, with all RCCS origin sites shipping to a single processing site. A U.S. geographic centroid represents the fictitious centralized destination. The other systems are regionalized, with sites shipping to either two, three, or four regional processing centers. Significant reductions in mileage, and therefore in risk, were found when two processing sites, rather than one, were considered. Additional processing sites did not provide substantial reductions compared with two sites.

5 U.S. Department of Energy, 1995, Operable Unit 3 Remedial Action Cost Estimate, Sections 1-3 and Appendixes A-C, Fernald Field Office, Fernald, Ohio. 
TABLE 1 Fixed and Variable Unit Costs by Cargo Type, Container Type, and Transport Mode

\begin{tabular}{cccc}
\hline Material & Transport Mode & $\begin{array}{c}\text { Fixed Cost per } \\
\text { Shipment (\$) }\end{array}$ & $\begin{array}{c}\text { Variable Cost per } \\
\text { Shipment-Mile (\$) }\end{array}$ \\
\hline \multirow{2}{*}{ RCCS in B-25-type boxes to disposal } & Truck & 335 & 1.43 \\
& Rail & 750 & $1.60-2.32^{\mathrm{a}}$ \\
RCCS in SeaLand-type containers to & Truck & 335 & 1.43 \\
processing sites & Rail & $910^{\mathrm{b}}$ & $1.60-2.32^{\mathrm{a}}$ \\
RCCS ingots or empty B-25-type & Truck & 335 & 1.43 \\
boxes & Rail & 750 & $1.60-2.32^{\mathrm{a}}$ \\
Secondary wastes to disposal & Truck & 880 & $4.00-5.94^{\mathrm{a}}$ \\
& Rail & 750 & $1.60-2.32^{\mathrm{a}}$ \\
\hline
\end{tabular}

a Unit costs decrease as shipping distances increase.

b Costs of a crane to load the SeaLand-type container onto the railcar are included.

Sources: Trucking costs from U.S. Department of Energy, 1995, Operable Unit 3 Remedial Action Cost Estimate, Sections 1-3 and Appendixes A-C, Fernald Field Office, Fernald, Ohio; and rail and secondary waste costs from Feizollahi, F., et al., 1994, Waste Management Facilities Cost Information for Transportation of Radioactive and Hazardous Materials, EGG-WM-10877-Rev. 1, EG\&G Idaho, Inc., Idaho Falls, Idaho. 


\section{GENERAL ASSUMPTIONS}

The assumptions made in this analysis generally follow those in the Waste Management Programmatic Environmental Impact Statement (WM PEIS) currently in preparation (DOE 1996). When necessary, the information from that effort has been supplemented by relevant cost-related information developed from current activities at the Fernald Environmental Management Project (FEMP), Fernald, Ohio.

\subsection{SHIPMENT CAPACITY}

Shipments of radioactively contaminated carbon steel (RCCS) to processing sites are assumed to be limited by restrictions on both vehicle weight and volume. Trucks are limited by. law to a gross load of $36,288 \mathrm{~kg}(80,000 \mathrm{lb})$. With a tractor-trailer mass of about $16,329 \mathrm{~kg}(36,000 \mathrm{lb})$, this limit results in a net payload of $19,458 \mathrm{~kg}$ (44,000 lb or 22 tons) (WM PEIS assumptions). The payload is assumed to be $54,431 \mathrm{~kg}(120,000 \mathrm{lb}$ or 60 tons) for railcar shipments on the basis of the median experience for recent years (WM PEIS assumptions). Shipment in 90,718-kg (100-ton) gondola railcars would increase the payload to $72,575 \mathrm{~kg}(160,000 \mathrm{lb}$ or 80 tons); this option is currently under consideration at FEMP.

SeaLand-type containers are assumed to be used for RCCS transport to processing sites because the use of these containers for bulk cargo reduces handling costs and risks. Only one loaded SeaLand-type container is assumed per truck or railcar; two empty containers per vehicle are assumed for the return trip. Transportation of RCCS in the form of $1 / 2$-ton ingots is also considered, with the cargo tied down on a flatbed trailer. For shipment of fabricated containers, a 13.7-m (45-ft) trailer is assumed.

\subsection{LOADING CHARACTERISTICS OF RADIOACTIVELY CONTAMINATED CARBON STEEL PRODUCTS}

Two types of RCCS products are evaluated: ingots and B-25-type boxes. Both are assumed to be produced from carbon steel. The costs to handle and transport contaminated materials depend on the type and size of the container. Table 2 shows the shipping and container characteristics assumed in this analysis.

For RCCS-fabricated containers, shipment capacity is determined by the volume of the empty containers. The numbers of containers that can be transported per shipment are shown in Table 2, along with container or product weight and volume. 
TABLE 2 Cargo Characteristics and Shipment Loading Assumptions for Radioactively Contaminated Carbon Steel

\begin{tabular}{|c|c|c|c|}
\hline RCCS Cargo & $\begin{array}{l}\text { Maximum } \\
\text { Loaded Unit } \\
\text { Weight (lb) }\end{array}$ & $\begin{array}{l}\text { Unit } \\
\text { Volume } \\
\left(\mathrm{ft}^{3}\right)\end{array}$ & $\begin{array}{c}\text { Units per } \\
\text { Shipment } \\
\text { (Truck/Rail }^{\mathrm{a}} \text { ) }\end{array}$ \\
\hline RCCS in B-25-type boxes to disposal ${ }^{\mathrm{b}}$ & 8,800 & 90 & $10 / 11$ \\
\hline RCCS in SeaLand-type containers to processing ${ }^{c}$ & 44,000 & 1,200 & $1 / 1$ \\
\hline Ingots to disposal & 1,000 & 2 & $44 / 120$ \\
\hline B-25-type boxes to user sites & 800 & 90 & $28 / 30$ \\
\hline Secondary waste drums to disposal ${ }^{\mathrm{d}}$ & 1,200 & 7.4 & $36 / 120$ \\
\hline \multicolumn{4}{|l|}{ a Value given is on a per-railcar basis. } \\
\hline \multicolumn{4}{|l|}{ b Assumed RCCS packaged density of $45 \mathrm{lb} / \mathrm{ft}^{3}$. } \\
\hline \multicolumn{4}{|l|}{ c Assumed RCCS packaged density of $20 \mathrm{lb} / \mathrm{ft}^{3}$. } \\
\hline \multicolumn{4}{|l|}{ d Assumed secondary waste density of $180 \mathrm{lb} / \mathrm{ft}^{3}$. } \\
\hline Source: DOE (1995a). & & & \\
\hline
\end{tabular}

The form, density, and volume of RCCS will have a direct effect on the number of containers per shipment, the number of shipments required, and the total cost of shipping the inventory from one site to another. In this analysis, an RCCS density of $490.6 \mathrm{lb} / \mathrm{ft}^{3}$ (Perry et al. 1973 ) is assumed for ingots (i.e., a specific gravity of 7.86), and a density of $180 \mathrm{lb} / \mathrm{ft}^{3}$ is assumed for secondary wastes (average of values given for slag by Feizollahi and Shropshire [1993] and by Goyette [1995]). A packaged density of $20 \mathrm{lb} / \mathrm{ft}^{3}$ is assumed for unsegmented scrap in Sealand-type containers. Some segmentation is assumed for RCCS loading in B-25-type boxes, raising the density to $45 \mathrm{lb} / \mathrm{ft}^{3}$. In general, the volume after packaging is greater than the initial RCCS volume; the ratio of the packaged volume to the initial or theoretical volume is called the bulking factor (also known as the packing efficiency) and, on the basis of experience at FEMP (unpublished information), is assumed in this analysis to have a value of 25 . 


\section{RISK ASSESSMENT}

The transportation risk factors generated by this analysis are unit-risk factors (in fatalities per vehicle-mile) for shipment by truck or train. The assumed radiological characteristics of the cargo, the technical approach, calculations, and results are presented in the following paragraphs.

\subsection{RADIOLOGICAL CHARACTERISTICS}

Radiological risks associated with transporting the RCCS, its products (i.e., ingots or fabricated containers), and secondary wastes are directly related to the radiological characteristics of the material. The key characteristics include the radioactivity level and the radionuclide profile (i.e., isotopic distribution). Both the level and profile would vary among fuel cycle facilities and processes, as well as metals and end products. For the purpose of characterization, the cargo materials considered for risk assessment include the RCCS packaged in B-25-type boxes, RCCS packaged in SeaLand-type containers, ingots, empty B-25-type boxes, and secondary wastes from processing packaged in drums.

The radioactivity levels of the RCCS within the U.S. Department of Energy (DOE) complex are generally not well known. Some existing information is compiled in Appendix A for a number of fuel cycle facilities, plus accelerators and other facilities that may contain naturally occurring radioactive materials. For lack of consistent data on the radioactivity levels at various facilities, the assumption is made that the RCCS would exhibit an external surface dose rate of $0.5 \mathrm{mrem} / \mathrm{h}$ when packaged for shipment. For ingots or empty fabricated containers, two possible radioactivity levels are assumed: (1) a concentration at $2 \mathrm{nCi} / \mathrm{g}$, a threshold limit below which the material is no longer considered as radioactive by the U.S. Department of Transportation (49 CFR Part 173); and (2) a concentration specified by constraining worker and public risk scenarios associated with metal smelting operations (Simek 1995). The U.S. Department of Transportation limit of $2 \mathrm{nCi} / \mathrm{g}$ was found to be more constraining and was used in this assessment of transportation risks. The secondary wastes from the RCCS processing are assumed to be shipped as low-level radioactive waste to a licensed burial site. For such wastes, the risk factors are assumed to be the same as for low-level radioactive waste analyzed in the ongoing WM PEIS, which assumes an external dose rate of $1 \mathrm{mrem} / \mathrm{h}$ at $1 \mathrm{~m}$ from the package surface. Table 3 summarizes the various radiological characteristics.

Assessing radiological risks depends on the radionuclide profile of the metals. Radiological profile data are compiled and discussed in Appendix A for the following fuel cycle facilities: uranium enrichment, manufacturing (úranium and plutonium), tritium production, - reactor/ accelerator, fuel processing, and facilities involving naturally occurring radioactive materials. The 


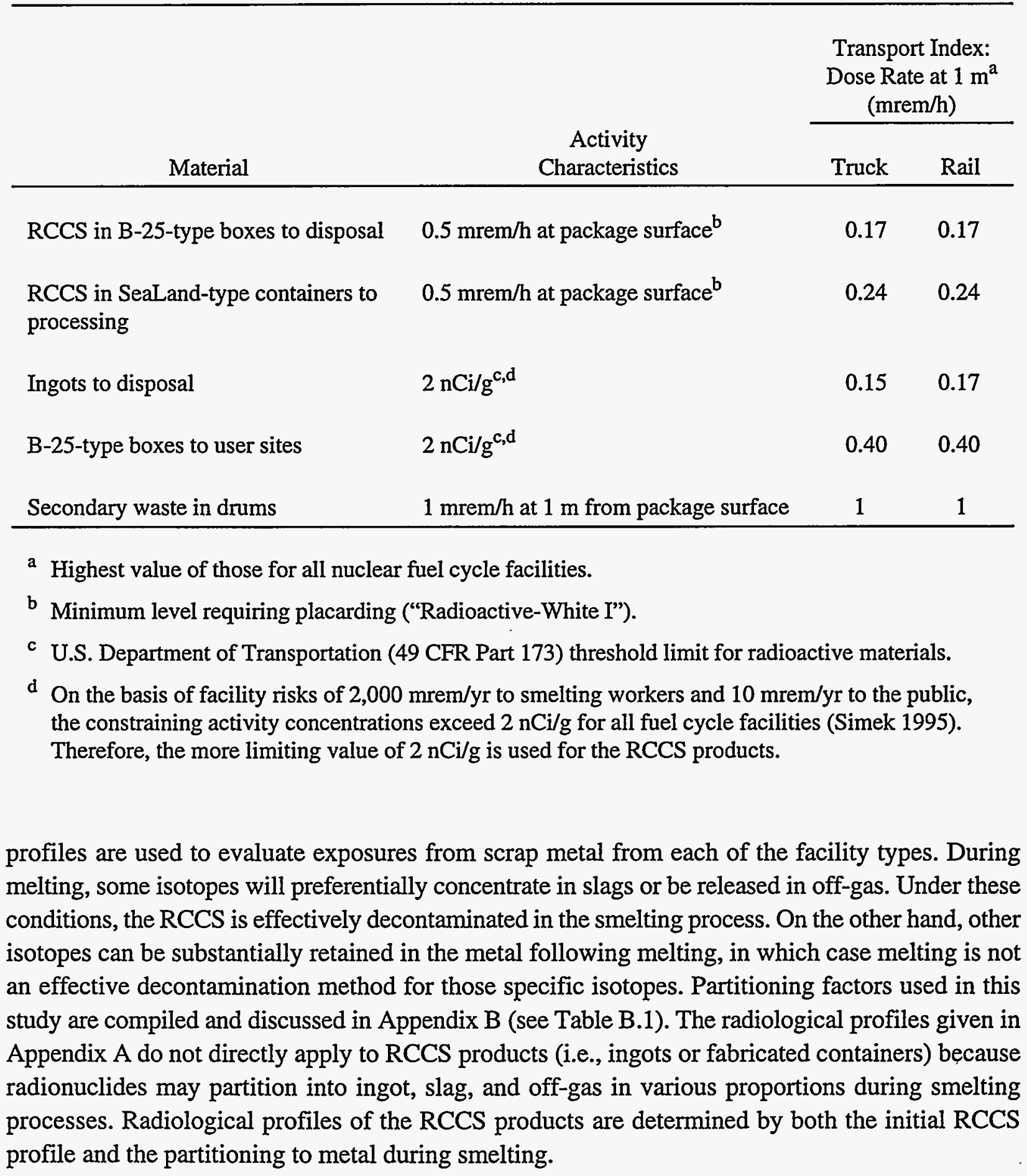




\subsection{TECHNICAL APPROACH}

The transportation risk assessment approach shown in Figure 1 is consistent with that developed by Chen et al. (1995) for the WM PEIS (formerly known as the Environmental Management Programmatic Environmental Impact Statement). Two major components of population risks are analyzed: cargo-related risk and vehicle-related risk. Risks would be associated with radiological exposures from the RCCS during routine transportation operations or in accident conditions. Risks for routine operations include those affecting the population (residents) along the route, passengers sharing the road, the population at vehicle stops, and vehicle crew members. In contrast, accident risks would only be associated with the potential for dispersed radioactive contents from an accident. Cargo-related radiological dose (in person-rem) is assessed with the RADTRAN 4 computer code (Neuhauser and Kanipe 1993). Human health risks are calculated by using the health risk conversion factors published by the International Commission on Radiological Protection (ICRP 1991). These factors are $4 \times 10^{-4}$ latent cancer fatalities per person-rem for workers and $5 \times 10^{-4}$ latent cancer fatalities per person-rem for the general public. A risk factor of $1 \times 10^{-4}$ per person-rem is used for nonfatal cancers. Adding the risk factor for severe genetic effects, $1.3 \times 10^{-4}$ per personrem, brings the risk factor for total health detriment from radiation to $7.3 \times 10^{-4}$ per person-rem.

Risks associated with vehicle operation (independent of cargo type) include traffic accident fatalities and potential cancer fatalities from vehicle exhaust emissions. National traffic fatality and injury statistics (Saricks and Kvitek 1994) have been used to estimate the transportation accident risks. These risks are $3.1 \times 10^{-8}$ estimated fatalities per shipment-mile for truck transport and $3.8 \times 10^{-8}$ for railcar transport. Injury risks are $1.9 \times 10^{-7}$ and $8.7 \times 10^{-7}$ per shipment-mile for truck and rail transport, respectively. These values reflect multiyear data for registered interstate carriers using combination trucks and for freight transport by American Association of Railroads member carriers. These statistics are comparable to those for nuclear industry shipment of low-level waste. Risk factors associated with vehicle exhaust fumes are assumed to be $8.1 \times 10^{-9}$ per truck-mile and $1.0 \times 10^{-8}$ per railcar-mile for assessing latent mortality from pollutant inhalation (derived from Rao et al. 1982). Risk factors for nonfatal illnesses from vehicle emissions were not identified. The value per railcar-mile is calculated by allocating locomotive emissions among 60 railcars. Because population density and roadway congestion are less elsewhere, this factor only applies to urban population zones. The population densities used (persons per square mile) to analyze risks along the routes are 15 for rural areas, 1,864 for suburban areas, and 10,000 for urban areas (NRC 1977).

Total RCCS transportation risks (in terms of potential fatalities, injuries, or other radiation effects) for an origin-destination pair can be obtained by multiplying the unit-risk factor by the shipment mileage. The calculation of total risk (TR) for a particular alternative is expressed by

$$
T R_{k}=\Sigma_{i} \Sigma_{j} R_{i, j, k} \times Q_{i, j, k} \times M_{i, j, k}
$$




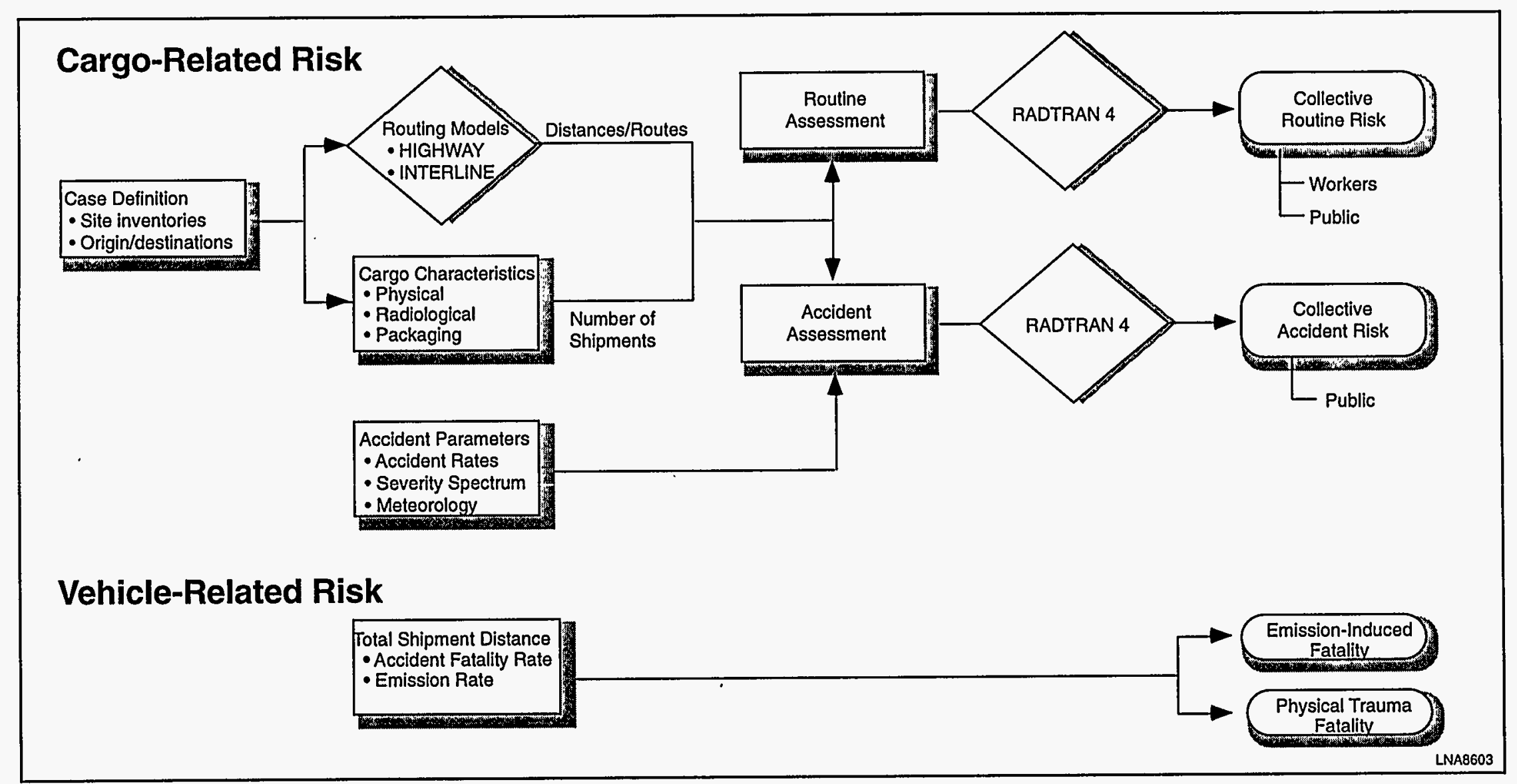

FIGURE 1 Flow Diagram for Transportation Risk 
where

$$
\begin{aligned}
i= & \text { the RCCS origin site, } \\
j= & \text { the RCCS destination site, } \\
k= & \text { alternative container type, transportation mode, and processing system } \\
& \text { configuration being considered, } \\
R_{i, j, k}= & \begin{array}{l}
\text { unit-risk factor for transporting RCCS by truck or rail (fatalities, } \\
\end{array} \\
Q_{i, j, k}= & \text { quantity of RCCS to be transported from origin site } i \text { to destination site } j \\
& \text { under option } k \text { (number of shipments), and }
\end{aligned}
$$

\subsection{CALCULATION OF UNIT-RISK FACTORS}

\subsubsection{Routine Operations}

The cargo-related radiological dose from routine operations is characterized by the external dose rate of the shipment. This value is typically represented by the transport index, which is a measure of dose rate (in millirem per hour at $1 \mathrm{~m}$ from the surface of conveyance). The transport index is dependent on the radioactivity level, radionuclide composition, package size, contents, and configuration. The values for the transport index have been calculated by using the MICROSHIELD code (Negin and Worku 1992) with the packaging information provided in Section 1 and the radiological data provided in Section 2.1. These values are provided in Table 3.

\subsubsection{Accident}

The cargo-related radiological accident doses are generally insignificant because the radioactive contents from the RCCS or its products are virtually nondispersible. Accident risks are obtained from RADTRAN 4 (Neuhauser and Kanipe 1993) calculations. The accident release fractions are assumed to follow NUREG-0170 (NRC 1977) for low-level waste. Additionally, the particulate aerosolized fraction and the respirable fraction applied to RCCS $\left(10^{-6}\right.$ and 0.05 , respectively) are specific to immobilized activity (e.g., contaminated metal), as suggested by RADTRAN 4. Because radioactive contaminants are immobilized in ingots and RCCS-fabricated 
boxes and because it is not possible for them to be dispersed in an accident, the related accident risks for these RCCS products are zero.

\subsubsection{Results}

Table 4 provides unit-risk factors for transporting the RCCS and its products and shows that traffic accidents are the major source of risk. Except for secondary-waste risk, which is derived from the WM PEIS estimates, the radiological unit-risk factors shown in Table 4 represent the highest risk factors among RCCS and its associated products (ingots and B-25-type boxes) from all nuclear fuel cycle facilities. For the RCCS products, a radioactivity content of $2 \mathrm{nCi} / \mathrm{g}$ was assumed. These risk factors represent the upper bound of potential risks associated with radiological effects of shipment of RCCS and its products on the basis of the facility radiological profiles. Two risk factor measures are presented: fatalities; and total health detriment, including fatal and nonfatal cancers, injuries, and severe genetic effects. Table 4 shows that the transportation-related risks from RCCS and its products are primarily attributable to nonradiological causes, such as traffic accidents. This fact is shown even more clearly in Figure 2, which graphs the proportion of total risk that is due to each risk type. The unit-risk factors are generally comparable for the truck and rail modes, although those for rail transport are somewhat higher, especially for traffic accident injuries. Slightly higher risk levels are estimated for the secondary wastes because of the higher radiation levels assumed. 
TABLE 4 Unit-Risk Factors for RCCS and Associated Materials (Estimated Health Effects per Shipment-Mile)

\begin{tabular}{|c|c|c|c|c|c|c|c|c|c|c|c|}
\hline \multirow[b]{3}{*}{ Cargo } & \multirow{3}{*}{$\begin{array}{l}\text { Health } \\
\text { Effect } \\
\text { Type }^{\mathrm{a}}\end{array}$} & \multicolumn{5}{|c|}{ Truck } & \multicolumn{5}{|c|}{ Rail } \\
\hline & & \multicolumn{2}{|c|}{ Cargo-Related } & \multicolumn{2}{|c|}{ Vehicle-Related } & \multirow[b]{2}{*}{ Total } & \multicolumn{2}{|c|}{ Cargo-Related } & \multicolumn{2}{|c|}{ Vehicle-Related } & \multirow[b]{2}{*}{ Total } \\
\hline & & $\begin{array}{l}\text { External } \\
\text { Exposure }\end{array}$ & $\begin{array}{l}\text { Accident } \\
\text { Rclease }\end{array}$ & $\begin{array}{c}\text { Exhaust } \\
\text { Emissions }^{\mathrm{b}}\end{array}$ & $\begin{array}{c}\text { Traffic } \\
\text { Accident }\end{array}$ & & $\begin{array}{l}\text { External } \\
\text { Exposure }\end{array}$ & $\begin{array}{l}\text { Accident } \\
\text { Release }\end{array}$ & $\begin{array}{c}\text { Exhaust } \\
\text { Emissions }{ }^{b}\end{array}$ & $\begin{array}{c}\text { Traffic } \\
\text { Accident }\end{array}$ & \\
\hline $\begin{array}{l}\text { RCCS in B-25-type } \\
\text { boxes to disposal }\end{array}$ & $\begin{array}{l}\mathrm{F} \\
\mathrm{T}\end{array}$ & $\begin{array}{l}5.1 \times 10^{-9} \\
7.3 \times 10^{-9}\end{array}$ & $\begin{array}{l}5.5 \times 10^{-14} \\
8.0 \times 10^{-14}\end{array}$ & $\begin{array}{l}8.1 \times 10^{-9} \\
8.1 \times 10^{-9}\end{array}$ & $\begin{array}{l}3.1 \times 10^{-8} \\
2.2 \times 10^{-7}\end{array}$ & $\begin{array}{l}4.5 \times 10^{-8} \\
2.4 \times 10^{-7}\end{array}$ & $\begin{array}{l}1.4 \times 10^{-9} \\
2.0 \times 10^{-9}\end{array}$ & $\begin{array}{l}6.3 \times 10^{-14} \\
9.3 \times 10^{-14}\end{array}$ & $\begin{array}{l}1.0 \times 10^{-8} \\
1.0 \times 10^{-8}\end{array}$ & $\begin{array}{l}3.8 \times 10^{-8} \\
9.0 \times 10^{-7}\end{array}$ & $\begin{array}{l}5.0 \times 10^{-8} \\
9.2 \times 10^{-7}\end{array}$ \\
\hline $\begin{array}{l}\text { RCCS in SeaLand- } \\
\text { type containers to } \\
\text { processing sites }\end{array}$ & $\begin{array}{l}\mathrm{F} \\
\mathrm{T}\end{array}$ & $\begin{array}{l}4.9 \times 10^{-9} \\
7.1 \times 10^{-9}\end{array}$ & $\begin{array}{l}5.5 \times 10^{-14} \\
8.0 \times 10^{-14}\end{array}$ & $\begin{array}{l}8.1 \times 10^{-9} \\
8.1 \times 10^{-9}\end{array}$ & $\begin{array}{l}3.1 \times 10^{-8} \\
2.2 \times 10^{-7}\end{array}$ & $\begin{array}{l}4.4 \times 10^{-8} \\
2.4 \times 10^{-7}\end{array}$ & $\begin{array}{l}7.5 \times 10^{-10} \\
1.1 \times 10^{-9}\end{array}$ & $\begin{array}{l}6.3 \times 10^{-14} \\
9.3 \times 10^{-14}\end{array}$ & $\begin{array}{l}1.0 \times 10^{-8} \\
1.0 \times 10^{-8}\end{array}$ & $\begin{array}{l}3.8 \times 10^{-8} \\
9.0 \times 10^{-7}\end{array}$ & $\begin{array}{l}4.9 \times 10^{-8} \\
9.1 \times 10^{-7}\end{array}$ \\
\hline Ingots to disposal & $\begin{array}{l}\mathrm{F} \\
\mathrm{T}\end{array}$ & $\begin{array}{l}3.1 \times 10^{-9} \\
4.4 \times 10^{-9}\end{array}$ & $\begin{array}{l}0 \\
0\end{array}$ & $\begin{array}{l}8.1 \times 10^{-9} \\
8.1 \times 10^{-9}\end{array}$ & $\begin{array}{l}3.1 \times 10^{-8} \\
2.2 \times 10^{-7}\end{array}$ & $\begin{array}{l}4.3 \times 10^{-8} \\
2.2 \times 10^{-7}\end{array}$ & $\begin{array}{l}1.2 \times 10^{-9} \\
1.8 \times 10^{-9}\end{array}$ & $\begin{array}{l}0 \\
0\end{array}$ & $\begin{array}{l}1.0 \times 10^{-8} \\
1.0 \times 10^{-8}\end{array}$ & $\begin{array}{l}3.8 \times 10^{-8} \\
9.0 \times 10^{-7}\end{array}$ & $\begin{array}{l}5.0 \times 10^{-8} \\
9.2 \times 10^{-7}\end{array}$ \\
\hline $\begin{array}{l}\text { B-25-type boxes to } \\
\text { user sites }\end{array}$ & $\begin{array}{l}\mathrm{F} \\
\mathrm{T}\end{array}$ & $\begin{array}{l}1.3 \times 10^{-8} \\
1.8 \times 10^{-8}\end{array}$ & $\begin{array}{l}0 \\
0\end{array}$ & $\begin{array}{l}8.1 \times 10^{-9} \\
8.1 \times 10^{-9}\end{array}$ & $\begin{array}{l}3.1 \times 10^{-8} \\
2.2 \times 10^{-7}\end{array}$ & $\begin{array}{l}5.2 \times 10^{-8} \\
2.2 \times 10^{-7}\end{array}$ & $\begin{array}{l}3.0 \times 10^{-9} \\
4.3 \times 10^{-9}\end{array}$ & $\begin{array}{l}0 \\
0\end{array}$ & $\begin{array}{l}1.0 \times 10^{-8} \\
1.0 \times 10^{-8}\end{array}$ & $\begin{array}{l}3.8 \times 10^{-8} \\
9.0 \times 10^{-7}\end{array}$ & $\begin{array}{l}5.1 \times 10^{-8} \\
9.2 \times 10^{-7}\end{array}$ \\
\hline $\begin{array}{l}\text { Secondary waste in } \\
\text { drums to disposal }\end{array}$ & $\begin{array}{l}\mathrm{F} \\
\mathrm{T}\end{array}$ & $\begin{array}{l}3.0 \times 10^{-8} \\
4.3 \times 10^{-8}\end{array}$ & $\begin{array}{l}5.5 \times 10^{-14} \\
8.0 \times 10^{-14}\end{array}$ & $\begin{array}{l}8.1 \times 10^{-9} \\
8.1 \times 10^{-9}\end{array}$ & $\begin{array}{l}3.1 \times 10^{-8} \\
2.2 \times 10^{-7}\end{array}$ & $\begin{array}{l}6.9 \times 10^{-8} \\
2.8 \times 10^{-7}\end{array}$ & $\begin{array}{l}8.0 \times 10^{-9} \\
1.2 \times 10^{-8}\end{array}$ & $\begin{array}{l}6.3 \times 10^{-14} \\
9.3 \times 10^{-14}\end{array}$ & $\begin{array}{l}1.0 \times 10^{-8} \\
1.0 \times 10^{-8}\end{array}$ & $\begin{array}{l}3.8 \times 10^{-8} \\
9.0 \times 10^{-7}\end{array}$ & $\begin{array}{l}5.6 \times 10^{-8} \\
9.2 \times 10^{-7}\end{array}$ \\
\hline
\end{tabular}

a $F$ indicates fatalities; $T$ indicates total detriment, including fatal and nonfatal cancers, injuries, and severe genetic effects.

b Estimates are limited to latent cancer fatalities. 


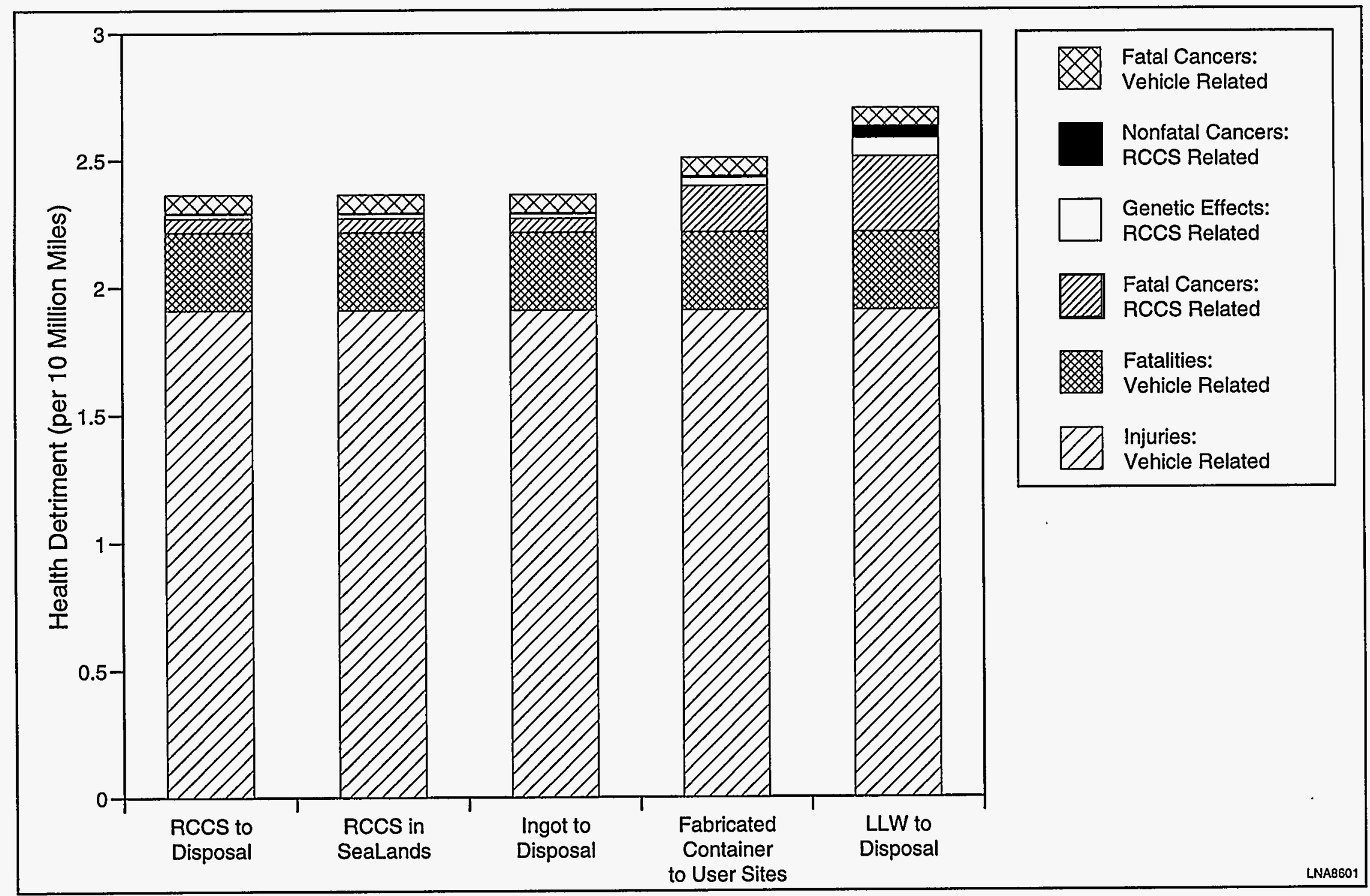

FIGURE 2 Components of Total Health Detriment from Truck Transportation (LLW = low-level waste) 


\section{ROUTING ANALYSIS}

A routing analysis was conducted to determine the highway and railway mileage between the origin and destination sites for the DOE policy options.

\subsection{TECHNICAL APPROACH}

To estimate transportation risks for a given system configuration, information is needed on the route and mileage connecting the origin and destination sites. Total aggregate risks can then be assessed from origin-destination pairs to evaluate possible alternatives. For this analysis, the representative routes were determined by the HIGHWAY 3.1 routing model (Johnson et al. 1993a) for truck routes and by INTERLINE 5.0 (Johnson et al. 1993b) for rail routes. In determining the appropriate routes, the U.S. Department of Transportation routing regulations for public highways were applied (49 CFR Part 177, docket HM-164).

For the purpose of analysis, four RCCS processing system scenarios are evaluated. The scenarios are developed to examine the impact of system configuration on transportation risks. For reference, the baseline shipment mileage is also estimated, by assuming shipment of RCCS from originating sites to the low-level waste disposal sites currently used by each site. The centralized scenario assumes one national processing site that accepts and processes RCCS from all DOE sites. The second scenario assumes two regional sites; an eastern processing site accepts RCCS from eastern DOE sites, and a western processing site accepts RCCS from western DOE sites.

In order to facilitate the analysis, geographic centroids are used as fictitious sites in the scenarios. The national centroid was determined by using the Digital Chart of the World database accessed by ARC/INFO. The eastern and western geographic centroids are determined after dividing the United States at the Mississippi River. The Mississippi River was chosen because the river represents a "natural" division of the continental United States. A three-region case was created that divides the contiguous U.S. land area approximately into thirds, retaining the eastern region and dividing the western region in half through the western centroid. For the four-region case, the eastern region was also divided in half through the eastern centroid. The geographic centroids are located as follows:

- Centralized Case. National centroid: latitude $39.642^{\circ}$ north, longitude $99.608^{\circ}$ west;

- Two-Region Case. Western centroid: latitude $39.790^{\circ}$ north, longitude $106.045^{\circ}$ west; eastern centroid: latitude $38.562^{\circ}$ north, longitude $82.645^{\circ}$ west; 
- Three-Region Case. Eastern centroid; southwest centroid: latitude $34.949^{\circ}$ north, longitude $103.952^{\circ}$ west; northwest centroid: latitude $39.790^{\circ}$ north, longitude $108.723^{\circ}$ west; and

- Four-Region Case. Southwest centroid; northwest centroid; southeast centroid: latitude $33.205^{\circ}$ north, longitude $85.781^{\circ}$ west; northeast centroid: latitude $41.287^{\circ}$ north, longitude $77.588^{\circ}$ west.

\subsection{RESULTS}

The origin-destination pairs and the mileage (truck and rail) for the centralized and two-processing-site scenarios for ingot or box production are presented in Table 5. All mileages presented here represent the origin-destination distances from actual generating sites to the fictitious sites under each option through the existing U.S. routing system. In addition, route mileages are given in Table 6 for shipments from the RCCS originating sites and from the conceptual processing sites to the customary disposal site for each originating site. For purposes of assessment, the percentage of travel in rural, suburban, and urban population density zones is assumed to be $90 \%$ rural, 5\% suburban, and 5\% urban for both truck and rail modes of transport (NRC 1977). 
TABLE 5 Highway and Railway Mileages between Origin and Processing Sites for the Centralized and Two-Regional-Site Scenarios ${ }^{\mathbf{a}}$

\begin{tabular}{|c|c|c|c|c|c|c|}
\hline \multirow[b]{3}{*}{ DOE Site } & \multicolumn{3}{|c|}{ Truck Route Distance (mi) } & \multicolumn{3}{|c|}{ Rail Route Distance (mi) } \\
\hline & \multirow[b]{2}{*}{$\begin{array}{c}\text { Central } \\
\text { Site }\end{array}$} & \multicolumn{2}{|c|}{ Two Sites } & \multirow{2}{*}{$\begin{array}{c}\text { Central } \\
\text { Site }\end{array}$} & \multicolumn{2}{|c|}{ Two Sites } \\
\hline & & Eastern & Western & & Eastern & Western \\
\hline ANL-East (east) & 728 & 500 & - & 792 & 472 & - \\
\hline ANL-West (west) & 986 & - & 781 & 1,414 & 一 & 693 \\
\hline Battelle Columbus (east) & 988 & 306 & - & 1,057 & 142 & - \\
\hline $\mathrm{BNL}$ (east) & 1,636 & 684 & 一 & 1,822 & 976 & - \\
\hline FEMP (east) & 918 & 225 & - & 1,016 & 198 & - \\
\hline General Atomics (west) & 1,491 & - & 1,026 & 1,983 & - & 1,756 \\
\hline Grand Junction (west) & 650 & - & 185 & 902 & 一 & 176 \\
\hline Hanford Site (west) & 1,402 & - & 1,197 & 1,794 & - & 1,655 \\
\hline LANL (west) & 817 & - & 500 & 944 & - & 515 \\
\hline LEHR (west) & 1,477 & - & 1,272 & 1,952 & - & 1,168 \\
\hline Mound Plant (east) & 956 & 263 & - & 1,428 & 172 & - \\
\hline Nevada Test Site (west) & 1,209 & - & 744 & 1,849 & - & 925 \\
\hline ORNL (east) & 1,065 & 321 & - & 1,168 & 411 & - \\
\hline Paducah GDP (east) & 778 & 497 & - & 935 & 485 & - \\
\hline Pinellas Plant (east) & 1,642 & 983 & 一 & 1,850 & 1,005 & - \\
\hline Portsmouth GDP (east) & 1,100 & 52 & - & 1,085 & 57 & - \\
\hline RMI site (east) & 1,199 & 381 & - & 1,174 & 328 & 一 \\
\hline Rocky Flats (west) & 420 & - & 93 & 727 & - & 205 \\
\hline Savannah River Site (east) & 1,323 & 534 & - & 1,464 & 597 & 一 \\
\hline SNL (west) & 843 & - & 526 & 1,027 & - & 583 \\
\hline SSFL (west) & 1,454 & - & 989 & 1,789 & - & 1,634 \\
\hline Vallecitos (west) & 1,568 & - & 1,363 & 2,014 & - & 1,294 \\
\hline Weldon Spring (west) & 559 & - & 902 & 591 & - & 1,056 \\
\hline
\end{tabular}

a ANL, Argonne National Laboratory; BNL, Brookhaven National Laboratory; FEMP, Fernald Environmental Management Project; GDP, Gaseous Diffusion Plant; LANL, Los Alamos National Laboratory; LEHR, Laboratory for Energy-Related Health Research; ORNL, Oak Ridge National Laboratory; RMI, Reactive Metals, Inc.; SNL, Sandia National Laboratories; and SSFL, Santa Susana Field Laboratory. Dash indicates not applicable. 
TABLE 6 Mileages between RCCS Origin, Processing, and Disposal Sites by Truck and Rail ${ }^{\mathrm{a}}$

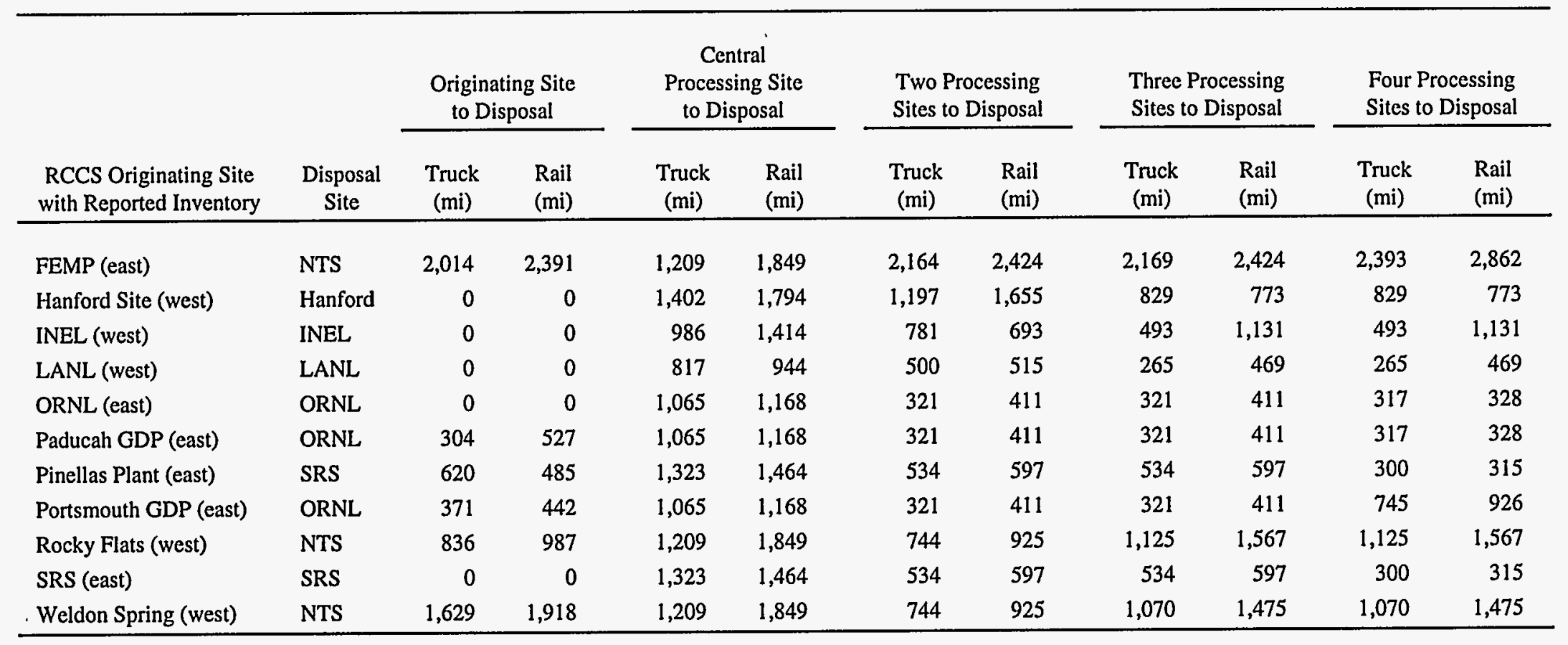

a FEMP, Fernald Environmental Management Project; GDP, Gaseous Diffusion Plant; INEL, Idaho National Engineering Laboratory; LANL, Los Alamos National Laboratory; NTS, Nevada Test Site; ORNL, Oak Ridge National Laboratory; and SRS, Savannah River Site. 


\section{COST ASSESSMENT}

Off-site shipping costs could potentially include (1) material handling and loading of the RCCS, ingots, or fabricated containers on the truck or railcar and (2) off-site transportation to the destination site. The off-site transportation costs in the WM PEIS were divided into two elements: a fixed cost (in terms of dollars per shipment) and a variable cost (in terms of dollars per shipment-mile). The values for the fixed and variable cost components were taken from WM PEIS references (Feizollahi et al. 1994) or were derived from recent FEMP cost estimates (unpublished data). The following cost elements were excluded from this analysis because they were not considered in the WM PEIS or recent FEMP cost literature:

- Rail storage yard upgrades (generally a site-specific issue);

- Maintenance of trucks or railcars and associated equipment (assumed in this analysis to be performed by the operating company);

- State permits or fees;

- Cost to decontaminate the railcars, truck trailers, and other equipment;

- Insurance and inspection costs;

- On-site shipping of RCCS to a central staging area; and

- Any truck loading and off-loading required for rail shipment of SeaLand-type containers (i.e., truck trailers on rail flatbed).

\subsection{TECHNICAL APPROACH}

The total cost (TC) for shipping RCCS from site $i$ to site $j$ under option $k$ would be determined by the following equation:

$$
T C_{i j, k}=\Sigma_{i} \sum_{j}\left\{F C_{k}+\left[V C_{k} \times M_{i, j, k}\right]\right\} \times Q_{i, j, k},
$$


where

$$
\begin{aligned}
& F C_{k}=\text { fixed transportation cost for truck or rail (dollars per shipment), } \\
& V C_{k}=\text { variable transportation cost for truck or rail (dollars per shipment-mile), }
\end{aligned}
$$

and the other terms are as defined for Equation 1.

The unit transportation cost per shipment $\left(C_{i, j, k}\right)$ is determined by calculating the total fixed and variable costs and then dividing by the shipping distance:

$$
C_{i, j, k}=\left\{F C+\left[V C_{k} \times M_{i, j, k}\right]\right\} / M_{i, j, k},
$$

where $C_{i, j, k}$ is the unit cost for transportation by truck or rail (dollars per shipment-mile).

Costs for loading (but not unloading) the B-25-type boxes on the truck or railcar are included in the fixed costs. Unloading is assumed to be incorporated into disposal or processing costs at the receiving site. The following information was used to calculate the costs of loading:

- A crew size of two laborers and one equipment operator for truck loading, and

- A loading rate of four B-25-type boxes per hour.

The number of required shipments is determined by either the maximum volume or the maximum mass of contents allowed. In general, when large containers, such as SeaLands, are used to transport RCCS, a major constraint will be the weight limit of the container. The assumption is that much of the RCCS will be structural steel or other relatively dense items and, therefore, may fill only a fraction of the volume of these containers when the weight limit of the container has been reached. The number of shipments $(Q)$ is calculated by

$$
Q_{\text {by weight }}=I_{i} \times D /\{P-[N \times W]\} \text {, }
$$

where

$$
\begin{aligned}
& I_{i}=\text { the RCCS inventory at site } i\left(\mathrm{ft}^{3}\right), \\
& D=\operatorname{RCCS} \text { density }\left(\mathrm{lb} / \mathrm{ft}^{3}\right), \\
& P=\text { payload capacity for truck or rail (lb), }
\end{aligned}
$$




$$
\begin{aligned}
& N=\text { number of containers per shipment for truck or rail, and } \\
& W=\text { container weight }(\mathrm{lb}) .
\end{aligned}
$$

The required number of containers for shipping RCCS to a processing site based on volume considerations is estimated by knowing the maximum volume of one container, the number of containers per shipment, and the bulking factor for the RCCS:

$$
Q_{\text {by volume }}=I \times B F /[N \times V] \text {, }
$$

where

$$
\begin{aligned}
B F & =\text { bulking factor, and } \\
V & =\text { volume of container }\left(\mathrm{ft}^{3}\right) .
\end{aligned}
$$

The bulking factor (also known as the packaging efficiency factor) is a function of the form of the material being transported; in this analysis, a uniform bulking factor of 25 is assumed on the basis of FEMP experience (unpublished data).

Shipment capacity for the B-25-type boxes fabricated from RCCS is limited only by volume restrictions, assuming that the containers would be shipped to the user site empty. Therefore, the number of shipments for these containers is determined on volume considerations only.

\subsection{RESULTS}

Results of the transportation unit-cost factors as a function of RCCS origin and destination sites are shown in Table 7 for RCCS transport to processing centers and for transport of the fabricated containers to the using site. Fixed and variable unit-cost factors are shown as a function of container type and shipping mode.

The results indicate that lower unit costs are associated with longer one-way distances, which is to be expected because fixed costs are then averaged over higher mileages. Lower unit costs for rail transport than for truck transport occur in part because of the heavier payload. The results in Table 7 are in general agreement with those seen previously for RCCS transport. Note that the costs per cubic foot for transporting B-25-type boxes are greater than for unprocessed RCCS because of the large void volume associated with the empty containers. 
TABLE 7 Unit Costs for RCCS Shipment as a Function of RCCS Cargo, Container Type, and Transport Mode

\begin{tabular}{|c|c|c|c|c|}
\hline Cargo Shipped & $\begin{array}{l}\text { Transport } \\
\text { Mode }\end{array}$ & $\begin{array}{l}\text { Fixed Cost per } \\
\text { Shipment }^{\mathrm{a}}(\$)\end{array}$ & $\begin{array}{l}\text { Variable Cost per } \\
\text { Shipment-Mile }^{\mathrm{a}}(\$)\end{array}$ & $\begin{array}{l}\text { Applicable } \\
\text { Mileage }\end{array}$ \\
\hline \multirow[t]{2}{*}{ RCCS in B-25-type boxes } & Truck & 335 & 1.43 & $0-9,999$ \\
\hline & Rail & 750 & $\begin{array}{l}2.32 \\
1.91 \\
1.60\end{array}$ & $\begin{array}{r}0-1,000 \\
1,000-2,000 \\
2,000-9,999\end{array}$ \\
\hline \multirow{2}{*}{$\begin{array}{l}\text { RCCS in top-loaded } \\
\text { SeaLand-type containers }\end{array}$} & Truck & 335 & 1.43 & $0-9,999$ \\
\hline & Rail & $910^{\mathrm{b}}$ & $\begin{array}{l}2.32 \\
1.91 \\
1.60\end{array}$ & $\begin{array}{r}0-1,000 \\
1,000-2,000 \\
2,000-9,999\end{array}$ \\
\hline \multirow[t]{2}{*}{ Ingots or B-25-type boxes } & Truck & 335 & 1.43 & $0-9,999$ \\
\hline & Rail & 750 & $\begin{array}{l}2.32 \\
1.91 \\
1.60\end{array}$ & $\begin{array}{r}0-1,000 \\
1,000-2,000 \\
2,000-9,999\end{array}$ \\
\hline \multirow[t]{2}{*}{ Secondary wastes in drums } & Truck & $880^{\mathrm{c}}$ & $4.00-5.94$ & 0-9,999 \\
\hline & Rail & 750 & $\begin{array}{l}2.32 \\
1.91 \\
1.60\end{array}$ & $\begin{array}{r}0-1,000 \\
1,000-2,000 \\
2,000-9,999\end{array}$ \\
\hline
\end{tabular}

a Variable cost per shipment-mile can be multiplied by origin-destination distance and then added to fixed cost to estimate total cost of loading and transport per shipment.

b Cost for crane to load SeaLand-type container on railcar included.

c Value reflects cost for material at $1 \mathrm{mrem} / \mathrm{h}$.

Sources: Trucking costs from DOE (1995a); rail and secondary waste costs from Feizollahi et al. (1994). 


\section{APPLICATION TO OPTIONS: AN EXAMPLE}

An example applying the unit-risk factors to the evaluation of the four processing site scenarios for ingot or RCCS box production is developed in the following paragraphs. This example is provided for illustration only; it is not based on adequate data for a definitive assessment of the alternatives. Transportation risks are only calculated for each of the sites for which an RCCS inventory estimate is available. Costs are not included in the example but are being addressed in the overall economic model.

The three RCCS management options and two of the site scenarios evaluated in the example are illustrated in Figures 3 through 5. Figure 3 shows the RCCS originating sites and their normal low-level waste disposal sites for option 1 . The example assumes that clean containers for disposal of RCCS under option 1 all originate from one site at the eastern centroid. This assumption is consistent with current practice. For options 2 and 3, risks are calculated for a centrally located processing site that would receive and process RCCS from all of the DOE sites for which inventory data are available (Figures $4 \mathrm{a}$ and $5 \mathrm{a}$ ) and for two processing sites serving the DOE sites in their respective regions (Figures $4 b$ and $5 b$ ).

Detail is only provided for the central and two-region processing scenarios in the tables that follow; information for the three-region and four-region processing site scenarios is presented in summary form. As shown in Figure 4, the RCCS under option 2 would be shipped to either a central or a regional processing site and then sent as ingots to the originating site's normal disposal site for burial. Figure 5 illustrates a similar process except that the B-25-type boxes produced would be shipped to user sites, and secondary waste would be sent to the originating site's normal disposal site. The sites used to evaluate the scenarios were chosen for data availability and ease of analysis. Their selection does not represent any DOE decision.

Data for the currently available scrap inventory of RCCS at $11 \mathrm{DOE}$ sites were taken from DOE (1995b). The sites, RCCS inventory, and shipment data derived from the cargo loading assumptions in Table 2 are shown in Table 8. The example is developed for the RCCS transport steps required in each of the scenarios, by truck and by rail. Shipment estimates for RCCS products are based on the inventory quantity of RCCS (not accounting for small losses in processing). Estimates of secondary waste shipments are based on the assumption, for illustrative purposes, that such wastes will constitute 5\% of the initial RCCS mass. Table 8 shows that the number of shipments required to deliver fabricated containers to user sites is slightly higher than that to ship the input RCCS to the processing center. This number is higher because of the greater void space in the shipment of empty boxes. The number of shipments for ingots is substantially lower because of the greater material density. 
RCCS Generating Site

斿 LLW Disposal Site

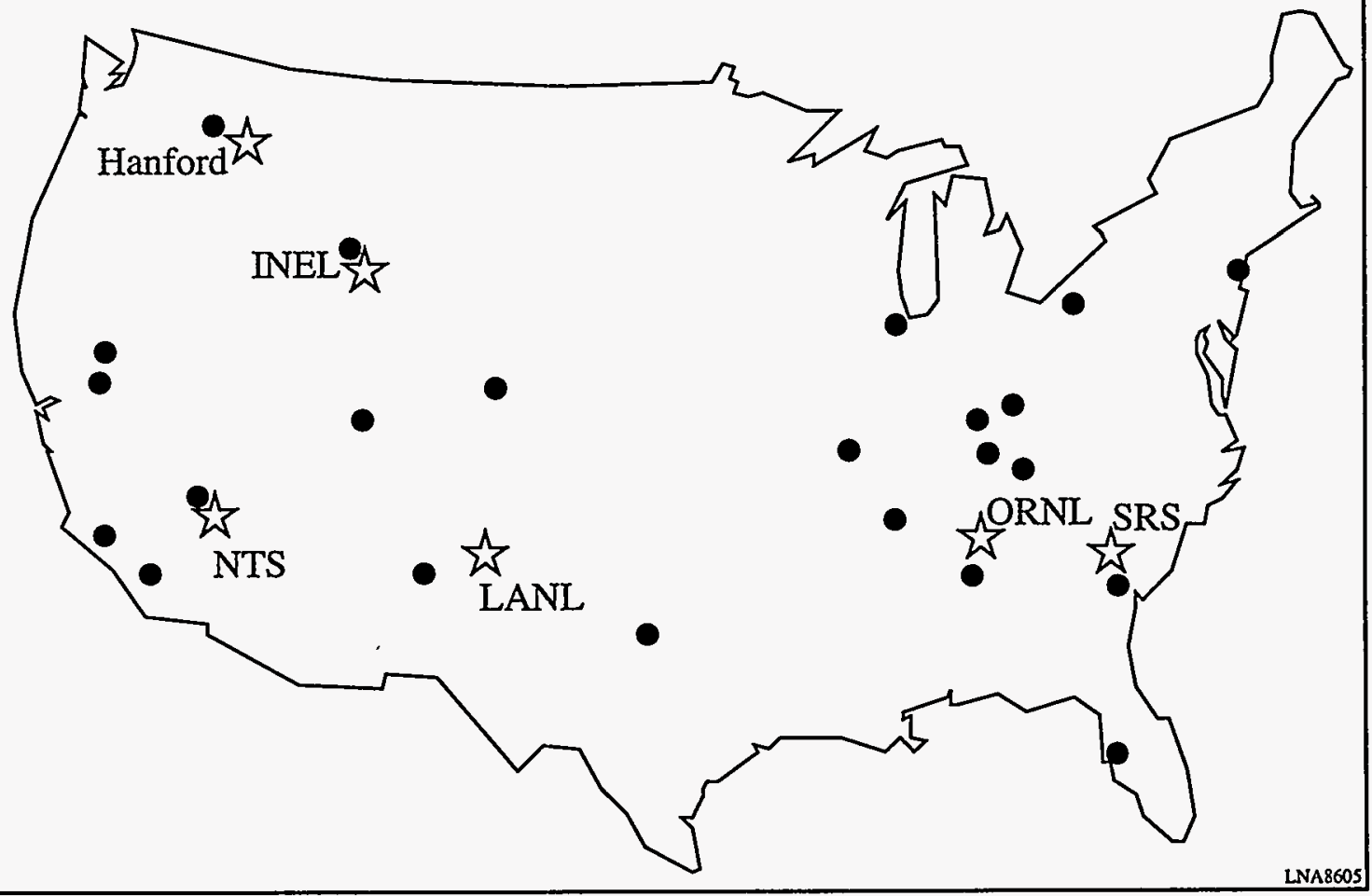

FIGURE 3 RCCS Disposal Scenario: Option 1 (INEL, Idaho National Engineering Laboratory; LANL, Los Alamos National Laboratory; LLW, low-level waste; NTS, Nevada Test Site; ORNL, Oak Ridge National Laboratory; and SRS, Savannah River Site)

Assessment of risk for each alternative first entails the calculation of shipment-miles for RCCS from each origin to each destination site. The sums of shipment-miles for the transportation steps involved in each policy option and for the central and regional processing site scenarios are shown in Table 9, based on the existing RCCS inventory masses and distribution among sites. The shipment-miles are multiplied by the unit-risk factors for each transport mode and cargo type (Table 4) to derive the total risk, as illustrated in Table 9 for potential fatalities. The transportation risks increase directly with the mileage required for each option. Nonradiological (i.e., vehicle-related) events are the primary cause (over 90\%) of the overall risks; among those events, traffic accidents are the single most significant cause. Mileages and estimated risks are similar for truck and rail transport, although slightly higher for rail. 


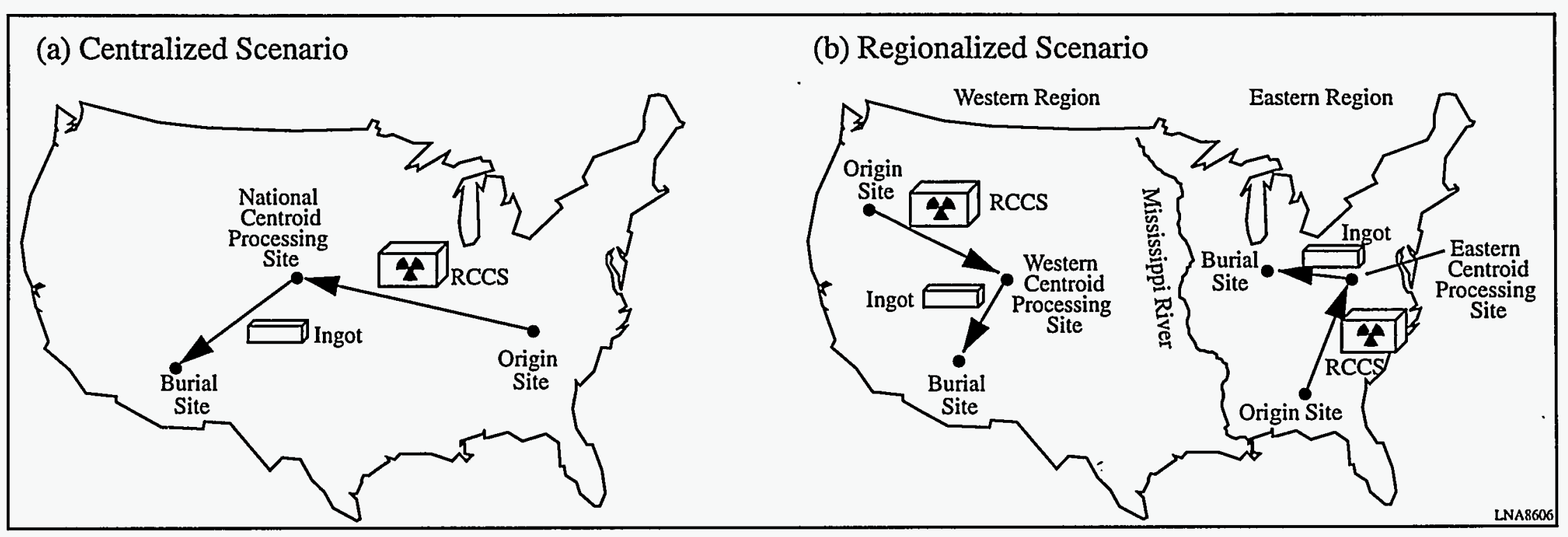

FIGURE 4 Scenarios for Ingot Processing and Disposal: Option 2 


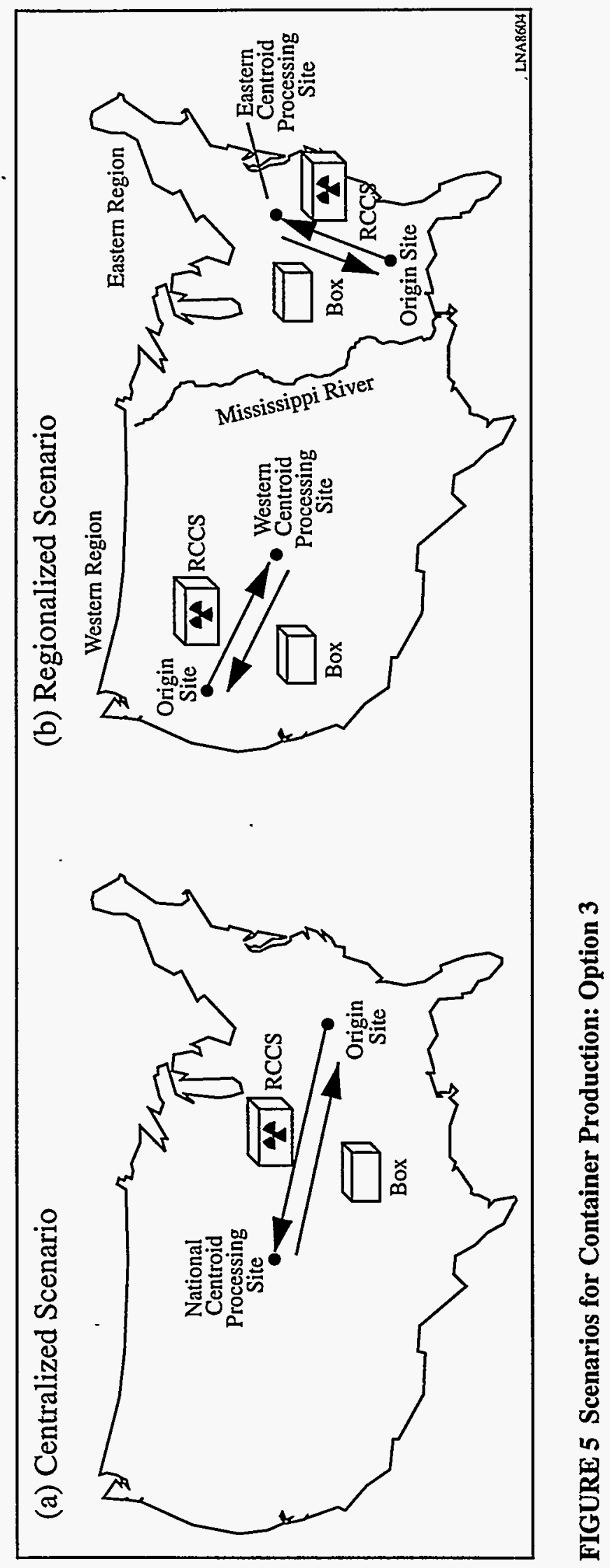


TABLE 8 RCCS Inventory and Shipment Estimates by Site, Cargo Type, and Shipment Mode

\begin{tabular}{|c|c|c|c|c|c|c|c|}
\hline \multirow[b]{2}{*}{ DOE Site ${ }^{a}$} & \multirow[b]{2}{*}{$\begin{array}{c}\text { RCCS } \\
\text { Inventory } \\
\text { (tons) }\end{array}$} & \multicolumn{6}{|c|}{ Number of Shipments (Truck/Rail) } \\
\hline & & $\begin{array}{c}\text { RCCS in B-25- } \\
\text { Type Boxes }\end{array}$ & $\begin{array}{c}\text { RCCS in } \\
\text { SeaLand-Type } \\
\text { Containers }\end{array}$ & $\begin{array}{c}\text { Empty } \\
\text { SeaLand-Type } \\
\text { Containers }\end{array}$ & Ingots & $\begin{array}{c}\text { B-25-Type } \\
\text { Boxes }\end{array}$ & $\begin{array}{c}\text { Secondary } \\
\text { Waste } \\
\text { in Drums } \\
\end{array}$ \\
\hline FEMP & 422 & $21 / 19$ & $33 / 33$ & $17 / 17$ & $21 / 8$ & $38 / 36$ & $1 / 1$ \\
\hline Hanford Site & 2,271 & $113 / 102$ & $178 / 178$ & $89 / 89$ & $109 / 38$ & $203 / 190$ & $6 / 2$ \\
\hline INEL & 574 & $29 / 26$ & $45 / 45$ & $23 / 23$ & $28 / 10$ & $52 / 48$ & $2 / 1$ \\
\hline LANL & 3,278 & $162 / 148$ & $257 / 257$ & $129 / 129$ & $157 / 55$ & $293 / 274$ & $8 / 3$ \\
\hline ORNL & 47,048 & $2,324 / 2,113$ & $3,676 / 3,676$ & $1,838 / 1,838$ & $2,241 / 785$ & $4,201 / 3,921$ & $109 / 33$ \\
\hline Paducah GDP & 46,108 & $2,277 / 2,070$ & $3,603 / 3,603$ & $1,802 / 1,802$ & $2,196 / 769$ & $4,117 / 3,843$ & $107 / 33$ \\
\hline Pinellas & 20 & $1 / 1$ & $2 / 2$ & $1 / 1$ & $1 / 1$ & $2 / 2$ & $1 / 1$ \\
\hline Portsmouth GDP & 10,773 & $532 / 484$ & $842 / 842$ & $421 / 421$ & $513 / 180$ & $962 / 898$ & $25 / 8$ \\
\hline Rocky Flats & 8,100 & $400 / 364$ & $633 / 633$ & $317 / 317$ & $386 / 135$ & $724 / 675$ & $19 / 6$ \\
\hline SRS & 9,342 & $462 / 420$ & $730 / 730$ & $365 / 365$ & $445 / 156$ & $835 / 779$ & $22 / 7$ \\
\hline Weldon Spring & 29,565 & $1,460 / 1,328$ & $2,310 / 2,310$ & $1,155 / 1,155$ & $1,408 / 493$ & $2,640 / 2,464$ & $69 / 21$ \\
\hline
\end{tabular}

a FEMP, Fernald Environmental Management Project; GDP, Gaseous Diffusion Plant; INEL, Idaho National Engineering Laboratory; LANL, Los Alamos National Laboratory; ORNL, Oak Ridge National Laboratory; and SRS, Savannah River Site.

b Data from DOE (1995b). 
TABLE 9 Risk Estimate Components for RCCS Shipments for Option Scenarios Involving Central or Two-Region Site Processing ${ }^{\mathrm{a}}$

\begin{tabular}{|c|c|c|c|c|c|c|}
\hline \multirow[b]{2}{*}{ RCCS Option } & \multirow[b]{2}{*}{ Scenario } & \multirow[b]{2}{*}{ Cargo } & \multicolumn{2}{|c|}{ Truck Shipments } & \multicolumn{2}{|c|}{ Rail Shipments } \\
\hline & & & $\begin{array}{l}\text { Distance } \\
\text { (mi) }\end{array}$ & $\begin{array}{l}\text { Total } \\
\text { Fatality } \\
\text { Risk }\end{array}$ & $\begin{array}{l}\text { Distance } \\
\text { (mi) }\end{array}$ & $\begin{array}{l}\text { Total } \\
\text { Fatality } \\
\text { Risk }\end{array}$ \\
\hline $\begin{array}{l}\text { Option 1: RCCS } \\
\text { to disposal }\end{array}$ & None & $\begin{array}{l}\text { RCCS in boxes } \\
\text { Clean boxes }\end{array}$ & $\begin{array}{l}3.6 \times 10^{6} \\
6.8 \times 10^{6}\end{array}$ & $\begin{array}{l}0.2 \\
0.3\end{array}$ & $\begin{array}{l}4.3 \times 10^{6} \\
7.0 \times 10^{6}\end{array}$ & $\begin{array}{l}0.2 \\
0.3\end{array}$ \\
\hline $\begin{array}{l}\text { Option 2: ingots } \\
\text { to disposal }\end{array}$ & Central & $\begin{array}{l}\text { RCCS in SeaLands } \\
\text { Empty SeaLands } \\
\text { Ingots } \\
\text { Secondary waste }\end{array}$ & $\begin{array}{l}1.1 \times 10^{7} \\
5.4 \times 10^{6} \\
8.4 \times 10^{6} \\
4.1 \times 10^{5}\end{array}$ & $\begin{array}{l}0.48 \\
0.21 \\
0.36 \\
0.03\end{array}$ & $\begin{array}{l}1.2 \times 10^{7} \\
6.1 \times 10^{6} \\
3.6 \times 10^{6} \\
1.6 \times 10^{5}\end{array}$ & $\begin{array}{l}0.6 \\
0.29 \\
0.18 \\
0.01\end{array}$ \\
\hline \multirow{3}{*}{$\begin{array}{l}\text { Option 3: B-25- } \\
\text { type boxes to user } \\
\text { sites }\end{array}$} & Two sites & $\begin{array}{l}\text { RCCS in SeaLands } \\
\text { Empty SeaLands } \\
\text { Ingots } \\
\text { Secondary waste }\end{array}$ & $\begin{array}{l}5.9 \times 10^{6} \\
3.0 \times 10^{6} \\
3.4 \times 10^{6} \\
1.7 \times 10^{5}\end{array}$ & $\begin{array}{l}0.26 \\
0.12 \\
0.15 \\
0.01\end{array}$ & $\begin{array}{l}6.8 \times 10^{6} \\
3.4 \times 10^{6} \\
1.5 \times 10^{6} \\
6.8 \times 10^{4}\end{array}$ & $\begin{array}{l}0.33 \\
0.16 \\
0.07 \\
0.004\end{array}$ \\
\hline & Central & $\begin{array}{l}\text { RCCS in SeaLands } \\
\text { Empty SeaLands } \\
\text { B-25-type boxes } \\
\text { Secondary waste }\end{array}$ & $\begin{array}{l}1.1 \times 10^{7} \\
5.4 \times 10^{6} \\
1.2 \times 10^{7} \\
4.1 \times 10^{5}\end{array}$ & $\begin{array}{l}0.48 \\
0.21 \\
0.64 \\
0.03\end{array}$ & $\begin{array}{l}1.2 \times 10^{7} \\
6.1 \times 10^{6} \\
1.3 \times 10^{7} \\
1.6 \times 10^{5}\end{array}$ & $\begin{array}{l}0.6 \\
0.29 \\
0.66 \\
0.01\end{array}$ \\
\hline & Two sites & $\begin{array}{l}\text { RCCS in SeaLands } \\
\text { Empty SeaLands } \\
\text { B-25-type boxes } \\
\text { Secondary waste }\end{array}$ & $\begin{array}{l}5.9 \times 10^{6} \\
3.0 \times 10^{6} \\
6.8 \times 10^{6} \\
1.7 \times 10^{5}\end{array}$ & $\begin{array}{l}0.26 \\
0.12 \\
0.35 \\
0.01\end{array}$ & $\begin{array}{l}6.8 \times 10^{6} \\
3.4 \times 10^{6} \\
7.2 \times 10^{6} \\
6.8 \times 10^{4}\end{array}$ & $\begin{array}{l}0.33 \\
0.16 \\
0.37 \\
0.004\end{array}$ \\
\hline
\end{tabular}

a Estimated fatalities based on 157,000 tons.

Transportation mileages and associated risks for the scenarios are then summarized in Table 10. The major difference in estimates among the options is that lower mileages and, therefore, lower risks are associated with option 1, disposal using clean containers. The lower total mileages for option 1 result because only one-way transport of RCCS is required and because higher RCCS packaging densities are assumed than for the other options. Risks for centralized processing of RCCS and delivery of ingots or boxes to dispersed sites under options 2 and 3 are two to three times those for option 1.

The relationship of total mileage to the increase in the number of processing sites is shown in Figure 6. The use of two regional processing sites, rather than a single central one, under options 2 and 3 reduces mileages and risks by half. Increasing the number of regional processing sites to three or four does not further reduce mileage because some major RCCS originating sites are located near the two-region scenario centroids. Results of the evaluation indicate that colocating processing sites with major RCCS sources would tend to minimize mileages and risks. 
TABLE 10 Risk and Mileage Summary for RCCS Policy Option Scenarios ${ }^{a}$

\begin{tabular}{|c|c|c|c|c|c|c|c|}
\hline \multirow[b]{2}{*}{$\begin{array}{l}\text { RCCS } \\
\text { Option }\end{array}$} & \multirow[b]{2}{*}{ Scenario } & \multicolumn{3}{|c|}{ Truck } & \multicolumn{3}{|c|}{ Rail } \\
\hline & & $\begin{array}{l}\text { Total } \\
\text { Shipment } \\
\text { Mileage } \\
\left(10^{6} \mathrm{mi}\right)\end{array}$ & $\begin{array}{l}\text { Estimated } \\
\text { Fatalities }\end{array}$ & $\begin{array}{l}\text { Total } \\
\text { Estimated } \\
\text { Health } \\
\text { Detriment }\end{array}$ & $\begin{array}{l}\text { Total } \\
\text { Shipment } \\
\text { Mileage } \\
\left(10^{6} \mathrm{mi}\right)\end{array}$ & $\begin{array}{c}\text { Estimated } \\
\text { Fatalities }\end{array}$ & $\begin{array}{c}\text { Total } \\
\text { Estimated } \\
\text { Health } \\
\text { Detriment }\end{array}$ \\
\hline $\begin{array}{l}\text { Option 1: } \\
\text { RCCS to } \\
\text { disposal }\end{array}$ & None & 10 & 0.4 & 3.2 & 11 & 0.5 & 14.1 \\
\hline \multirow{4}{*}{$\begin{array}{l}\text { Option 2: } \\
\text { ingots }\end{array}$} & Central & 25 & 1.1 & 5.9 & 22 & 1.1 & 20.0 \\
\hline & Two sites & 13 & 0.5 & 3.0 & 12 & 0.6 & 10.7 \\
\hline & Three sites & 13 & 0.6 & 3.1 & 12 & 0.6 & 10.7 \\
\hline & Four sites & 13 & 0.6 & 3.2 & 12 & 0.6 & 10.8 \\
\hline \multirow{4}{*}{$\begin{array}{l}\text { Option 3: } \\
\text { B-25- } \\
\text { type } \\
\text { boxes }\end{array}$} & Central & 29 & 1.4 & 7.0 & 31 & 1.6 & 28.7 \\
\hline & Two sites & 16 & 0.8 & 3.9 & 17 & 0.9 & 15.8 \\
\hline & Three sites & 16 & 0.8 & 3.6 & 17 & 0.8 & 15.3 \\
\hline & Four sites & 16 & 0.8 & 3.6 & 17 & 0.9 & 15.4 \\
\hline
\end{tabular}

a Based on 157,000-ton inventory.

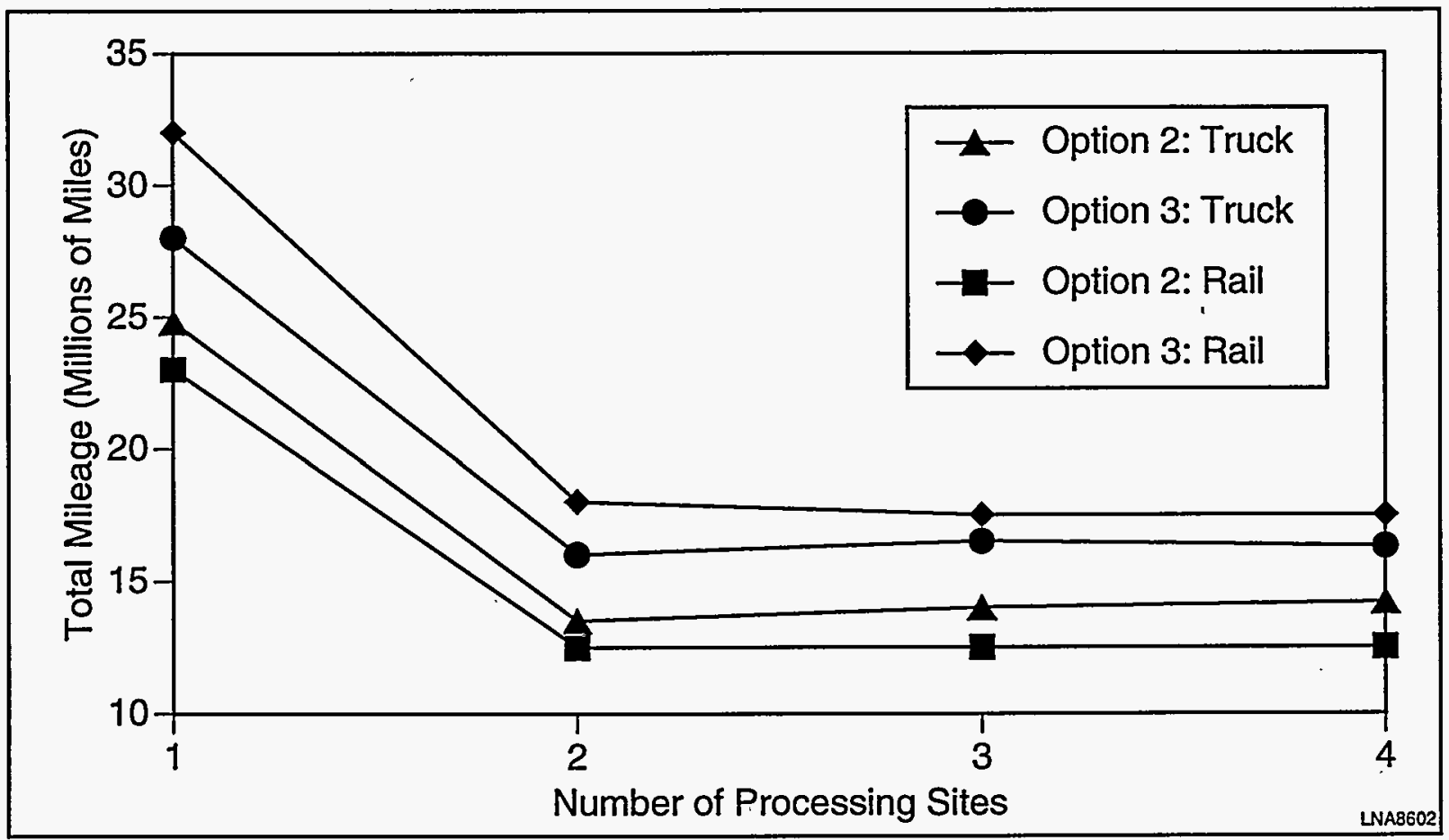

FIGURE 6 Response of Total Mileage to Number of Processing Sites 


\section{REFERENCES}

Chen, S.-Y., et al., 1995, “Assessment of Transportation Risk for the U.S. Department of Energy Environmental Management Programmatic Environmental Impact Statement," presented at WM '95 Conference, Tucson, Ariz., sponsored by the U.S. Department of Energy, March.

DOE: See U.S. Department of Energy.

Feizollahi, F., and D. Shropshire, 1993, Waste Management Facilities Cost Information Report for Greater-Than-Class $C$ and DOE Equivalent Special Case Waste, EGG-WM-10701, EG\&G Idaho, Inc., Idaho Falls, Idaho.

Feizollahi, F., et al., 1994, Waste Management Facilities Cost Information for Transportation of Radioactive and Hazardous Materials, EGG-WM-10877-Rev. 1, EG\&G Idaho, Inc., Idaho Falls, Idaho.

Goyette, M.L., 1995, Low-Level Waste Inventory, Characteristics, Generation, and Facility Assessment for Treatment, Storage, and Disposal Alternatives Considered in the U.S. Department of Energy Environmental Management Programmatic Environmental Impact Statement, ANL/EAD/TM-20 (Draft), Argonne National Laboratory, Argonne, Ill.

ICRP: See International Commission on Radiological Protection.

International Commission on Radiological Protection, 1991, "1990 Recommendation of the International Commission on Radiological Protection," ICRP Publication 60, Annals of the ICRP 21 (1-3), Pergamon Press, New York, N.Y.

Johnson, P.E., et al., 1993a, HIGHWAY 3.1, An Enhanced Transportation Routing Model: Program Description, Methodology, and Revised User's Manual, ORNL/TM-12124, Oak Ridge National Laboratory, Oak Ridge, Tenn., March.

Johnson, P.E., et al., 1993b, INTERLINE 5.0, An Expanded Railroad Routing Model: Program Description, Methodology, and Revised User's Manual, ORNL/TM-12090, Oak Ridge National Laboratory, Oak Ridge, Tenn., March.

Negin, C., and G. Worku, 1992, MICROSHIELD Version 4, Grove 92-2, Grove Engineering, Inc., Rockville, Md.

Neuhauser, K.S., and F.L. Kanipe, 1993, RADTRAN 4: Volume II. Technical Manual, SAND89-2370-Vol. 2, Sandia National Laboratories, Albuquerque, N.M., Aug. 
NRC: See U.S. Nuclear Regulatory Commission.

Perry, R.H., et al. (editors), 1973, Chemical Engineers' Handbook, 5th ed., McGraw-Hill Book Co., New York, N.Y.

Rao, R.K., et al., 1982, Non-Radiological Impacts for Transporting Radioactive Material, SAND81-1703, TTC-0236, Sandia National Laboratories, Albuquerque, N.M.

Saricks, C., and T. Kvitek, 1994, Longitudinal Review of State-Level Accident Statistics for Carriers of Interstate Freight, ANL/ESD/TM-68, Argonne National Laboratory, Argonne, Ill.

Simek, M.A., 1995, personal communication from Simek (Oak Ridge National Laboratory, Oak Ridge, Tenn.) to S.-Y. Chen (Argonne National Laboratory, Argonne, Ill.), Aug. 23.

U.S. Department of Energy, 1995a, Operable Unit 3 Remedial Action Cost Estimate, Sections 1-3 and Appendixes A-C, Fernald Field Office, Fernald, Ohio.

U.S. Department of Energy, 1995b, U.S. Department of Energy Scrap Metal Inventory Report for the Office of Technology Development, Office of Environmental Management, DOE/HWP-167, Oak Ridge Operations Office, Hazardous Waste Remedial Actions Program, Oak Ridge, Tenn., March.

U.S. Department of Energy, 1996, Draft Waste Management Programmatic Environmental Impact Statement for Managing Treatment; Storage, and Disposal of Radioactive and Hazardous Waste, Office of Environmental Management, Washington, D.C., April.

U.S. Nuclear Regulatory Commission, 1977, Final Environmental Statement on the Transportation of Radioactive Material by Air and Other Modes, NUREG-0170, Washington, D.C. 


\section{APPENDIX A:}

\section{RADIOLOGICAL PROFILE OF RADIOACTIVE SCRAP METALS AT DOE FUEL CYCLE FACILITIES}

In support of the risk calculation for the U.S. Department of Energy (DOE) "Recycle 2000" initiative, the radiological profiles of radioactive scrap metals have been collected and compiled for several DOE fuel cycle facilities. Because of the scarcity of existing data, the information presented here is intended to serve as baseline data for the analyses. As more information becomes available through the increased activities for facility decontamination and decommissioning, this baseline information will be revised and updated.

Data compiled in this appendix are derived from (1) direct inquiry to DOE sites, (2) a literature search through the DOE Remedial Action Program Information Center, and (3) engineering judgment. Data collection focused on carbon steel, which is the source material for the "Recycle 2000" initiative. The DOE fuel cycle facilities for which the data were collected include the following: uranium enrichment, uranium or plutonium manufacturing, tritium production, reactor/accelerator, fuel reprocessing, and naturally occurring radioactive material. Data are discussed in the following paragraphs by facility type.

\section{A.1 URANIUM ENRICHMENT FACILITY}

Information about uranium enrichment facilities has been documented by Myers et al. (1987), Gregory et al. (1990), Anderson et al. (1993), and Gilbert et al. (1993). The most detailed accounts of radiological profiles are provided in the reports by Myers et al. (1987) and by Gregory et al. (1990), which provide surveyed data for the three enrichment plants in the United States: the Oak Ridge Gaseous Diffusion Plant (ORGDP), the Paducah Gaseous Diffusion Plant, and the Portsmouth Uranium Enrichment Complex. Items covered include carbon steel, aluminum, stainless steel, copper, brass, mixed metal, steel tube sheets, $\mathrm{UF}_{6}$ cylinders, nickel ingots, and aluminum ingots. The majority of the inventory is steel. Data for ORGDP and the Paducah Gaseous Diffusion Plant are quite similar, while data for the Portsmouth Uranium Enrichment Complex are not as well characterized. For this reason, the data from ORGDP are treated as representative.

The ORGDP is a high-enrichment facility with a capacity for enrichment over $20 \%$. The following is a list of contaminants in the metals: uranium, $<500 \mathrm{ppm}$ (normal, depleted, and enriched [1.5\%]); Tc-99, <5.0 ppm; Np-237, <0.05 ppb; and Pu-239, <0.05 ppb (Myers et al. 1987). These data are essentially the same as those reported by Gregory et al. (1990). 
The activity profile (Table A.1) assumes that a portion of the scrap metal is derived from depleted-uranium operations (40\%) and that some is contaminated with enriched uranium (60\%). With the assumptions that the depleted uranium contains $0.15 \%$ (by weight) of U-235 (and no U-234) and that the enriched uranium contains $1.5 \%$ (by weight) of U-235 (and U-234), the average weight proportions of the metal are estimated to be $0.93 \%$ for U-235 and $0.87 \%$ for U-234.

\section{A.2 MANUFACTURING FACILITIES}

\section{A.2.1 Uranium Manufacturing Facility}

Data for uranium manufacturing facilities are derived from Myers et al. (1987), Gregory et al. (1990), and Burns (1995). All sources are related to the Feed Material Production Center at Fernald Environmental Management Project (FEMP). The report by Gregory et al. (1990) provided the following profile: uranium, $250 \mathrm{ppm}$ (98.5\% U-238 and 1.5\% U-235); Tc-99, 5 ppm; Np-237, $0.05 \mathrm{ppb} ; \mathrm{Pu}-239,0.05 \mathrm{ppb}$; and trace amounts of thorium isotopes. Data from Burns (1995) consist of surveillance data on FEMP facilities; for instance, data taken from Plant 9 (former uranium metal milling/processing facility) indicated the following measurements on steel coatings: U-234, 4,400 pCi/g; U-235/U-236, 570 pCi/g; U-238, 4,300 pCi/g; Tc-99; 600 pCi/g; and Th-230, 26 pCi/g. The two reports agree reasonably well on U-235 and U-238 but not on Tc-99 and U-234. A review of the other facilities at FEMP also revealed varying degrees of consistency in the profile. Because data provided by Burns (1995) represent the latest site surveillance data, they are therefore used to represent similar facilities. Such a profile is provided in Table A.2.

TABLE A.1 Activity Profile for Scrap Metal from a Uranium Enrichment Facility

\begin{tabular}{|c|c|c|}
\hline Nuclide & $\begin{array}{l}\text { Estimated Activity } \\
\text { Level }^{\mathrm{a}}(\mathrm{Bq} / \mathrm{g})\end{array}$ & Activity (\%) \\
\hline Tc-99 & 43,700 & 55 \\
\hline U-234 & 33,800 & 43 \\
\hline U-235 & 1,250 & 1.4 \\
\hline U-238 & 200 & 0.5 \\
\hline Pu-239 & 4 & 0.01 \\
\hline $\mathrm{Np}-237$ & 0.04 & 0.001 \\
\hline
\end{tabular}

a An upper-bound estimate. 
TABLE A.2 Activity Profile for Scrap Metal from a Uranium Manufacturing Facility

\begin{tabular}{lcc}
\hline & $\begin{array}{c}\text { Estimated Activity } \\
\text { Level (Bq/g) }\end{array}$ & Activity (\%) \\
\hline U-234 & 160 & 44 \\
U-238 & 160 & 43 \\
Tc-99 & 22 & 6 \\
U-235 & 20 & 6 \\
Th-230 & 1 & 1 \\
\hline
\end{tabular}

\section{A.2.2 Plutonium Manufacturing Facility}

Data for a plutonium manufacturing facility were obtained from the plutonium target radioactivity inventory as described for the New Production Reactor (DOE 1992). Table A.3 provides the breakdown of activity percentages by nuclide.

\section{A.3 TRITIUM PRODUCTION FACILITY}

Information about tritium production facilities is based on data collected from the Savannah River Site (Lutz 1995). The data combine the radiological profiles of the following metal sources: ramshorn piping, heat exchanger inlet pipe, expansion joints, pipe, heat exchanger heads, and slug buckets, which typically are made of stainless steel. For the purpose of preliminary analysis, the data are also assumed to apply to carbon steel products until better information is gathered from the site. The radiological profile is found in Table A.4.

\section{A.4 REACTOR AND ACCELERATOR}

\section{A.4.1 Light-Water Reactor}

Information about light-water reactors is based on reactor decommissioning waste and neutron-activated metals (Robertson et al. 1993). No specific characterization was available for scrap metals. Thus, contamination in the piping of the secondary coolant system (e.g., feedwater system) is used (Table A.5). In this system, contamination has been identified primarily as surface contamination. 
TABLE A.3 Activity

Profile for Scrap Metal

from a Plutonium

Manufacturing Facility

\begin{tabular}{lc}
\hline Nuclide & Activity (\%) \\
\hline $\mathrm{Pu}-241$ & 91 \\
$\mathrm{Pu}-239$ & 7.3 \\
$\mathrm{Pu}-240$ & 1.4 \\
$\mathrm{Pu}-238$ & 0.2 \\
$\mathrm{Am}-241$ & 0.2 \\
\hline
\end{tabular}

TABLE A.4 Activity Profile for Scrap Metal . from a Tritium Production Facility

\begin{tabular}{lcc}
\hline Nuclide & $\begin{array}{c}\text { Estimated Activity } \\
\text { Level (Bq/g) }\end{array}$ & Activity (\%) \\
\hline H-3 & 2,700 & 76 \\
Cs-137 & 250 & 11 \\
Sr-90 & 137 & 6 \\
Co-60 & 120 & 6 \\
Eu-152 & 21 & 1 \\
Am-241 & 4 & 0.1 \\
\hline
\end{tabular}

\section{A.4.2 Accelerator}

This information is based on Fermi National Accelerator Laboratory. The subject metal is carbon steel contaminated by neutron activation. The activity profile is based on the best judgment from the site expert, who indicated only the nuclide Mn-54 at an activity of $100 \%$. No estimate of absolute activity levels was available (Cupps 1995).

\section{A.5 FUEL REPROCESSING FACILITY}

This information is based on the West Valley Demonstration Project (Bridenbaker and Clemons 1987). For lack of precise data on metals, the information is inferred from the measurement of tank filters (Table A.6). No activity levels were provided for metals. 
TABLE A.5 Activity Profile for Piping from a Light-Water Reactor

\begin{tabular}{lcc}
\hline Nuclide & $\begin{array}{c}\text { Estimated Activity } \\
\text { Level }^{\mathrm{a}}\left(\mathrm{Bq} / \mathrm{cm}^{2}\right)\end{array}$ & Activity (\%) \\
\hline Nb-93m & 0.07 & 30 \\
Ni-63 & 0.06 & 24 \\
Co-60 & 0.04 & 18 \\
Mn-54 & 0.03 & 13 \\
C-14 & 0.013 & 6 \\
Fe-55 & 0.01 & 4 \\
Sr-90 & $5 \times 10^{-3}$ & 3 \\
Tc-99 & $1 \times 10^{-3}$ & 1 \\
Pu-238 & $9 \times 10^{-4}$ & 0.4 \\
Pu-239 & $6 \times 10^{-4}$ & 0.3 \\
Nb-94 & $6 \times 10^{-4}$ & - \\
Ni-59 & $5 \times 10^{-4}$ & - \\
I-129 & $8 \times 10^{-5}$ & - \\
Am-241 & $8 \times 10^{-5}$ & - \\
Cm-244 & $2 \times 10^{-5}$ & - \\
\hline
\end{tabular}

a Upper-bound estimate.

b Not determined.

TABLE A.6 Activity

Profile for a Fuel

Reprocessing Facility

\begin{tabular}{lc}
\hline Nuclide & Activity (\%) \\
\hline Cs-137 & 98 \\
Co-60 & 1 \\
Cs-134 & 1 \\
Sr-90 & 0.1 \\
Pu-239 & 0.001 \\
\hline
\end{tabular}

\section{A.6 NATURALLY OCCURRING RADIOACTIVE MATERIAL}

Information about naturally occurring radioactive material is based on the U.S. Environmental Protection Agency's compilation (EPA 1993) of piping-scale data from the petroleum industry. The contamination is on surfaces. The radiological profile is in Table A.7. 
TABLE A.7 Activity Profile for Naturally

Occurring Radioactive Material

\begin{tabular}{ccc}
\hline & $\begin{array}{c}\text { Estimated Activity } \\
\text { Level (Bq/g) }\end{array}$ & Activity (\%) \\
\hline Nuclide & & \\
Ra-226 & 13.3 & 27.3 \\
Th-228 & 4.4 & 9 \\
Pb-210 & 4.4 & 9 \\
Po-210 & 13.3 & 27.3 \\
\hline
\end{tabular}

\section{A.7 REFERENCES FOR APPENDIX A}

Anderson, L.M., et al., 1993, Y-12 Old Salvage Yard Scrap Metal Characterization Study, Waste Management and D\&D Division, Oak Ridge Y-12 Plant, Oak Ridge, Tenn., Nov.

Bridenbaker, W.A., and L. Clemons, 1987, Decommissioning of the Scrap Removal Room at the West Valley Demonstration Plant, DOE/NE/44139-33, West Valley Nuclear Services Company, West Valley, N.Y., Feb.

Burns, D.D., 1995, personal communication from Burns (Fernald Environmental Restoration Management Corporation, Fernald, Ohio) to S.-Y. Chen (Argonne National Laboratory, Argonne, II1.), June.

Cupps, V., 1995, personal communication from Cupps (Fermi National Accelerator Laboratory, Batavia, Ill.) to S.-Y. Chen (Argonne National Laboratory, Argonne, Ill.), June.

DOE: See U.S. Department of Energy.

EPA: See U.S. Environmental Protection Agency.

Gilbert, W.C., et al., 1993, "Contaminated Scrap Metal Management on the Oak Ridge Reservation," in Proceedings of Ninth Annual Oak Ridge Model Conference, Oak Ridge, Tenn., Aug.

Gregory, W.T., II, et al., 1990, Environmental Assessment of the Scrap Metal Program, Final Draft, Automated Sciences Group, Inc., Oak Ridge, Tenn., Aug.

Lutz, R., 1995, personal communication from Lutz (Savannah River Site, Savannah, S.C.) to S.-Y. Chen (Argonne National Laboratory, Argonne, Ill.), June. 
Myers, et al., 1987, DOE Scrap Metal Recovery Demonstration Project: Phase I Report, Vol. I, Babcock and Wilcox Nuclear Power Division, Lynchburg, Va., July 30.

Robertson, D.E., et al., 1993, Radionuclide Characterization of Reactor Decommissioning Waste and Neutron-Activated Metals, NUREG/CR-5894, prepared by Pacific Northwest Laboratory, Richland, Wash., for U.S. Nuclear Regulatory Commission, Washington, D.C., June.

U.S. Department of Energy, 1992, Environmental and Other Evaluation of Alternatives for Siting, Constructing, and Operating New Production Reactor Capacity, DOE/NP-0014, Office of New Production Reactors, Washington, D.C., Sept.

U.S. Environmental Protection Agency, 1993, Diffuse NORM Waste: Waste Characterization and Preliminary Risk Assessment, RAX10-9232/1-2, Draft, Office of Radiation and Indoor Air, Washington, D.C. 


\section{APPENDIX B:}

\section{RADIONUCLIDE PARTITIONING FACTORS IN THERMAL/MELT REFINING OF STEEL}

Traditionally, large-scale (nonradiologically specialized) metal-melting operations have employed blast furnaces, electric-arc furnaces, and basic oxygen systems in both the primary and secondary metal industries (Hertzler et al. 1993). In recent years, technologies such as induction and resistance furnaces have been determined to be suitable for processing radioactively contaminated metals. One example is the operation at the Scientific Ecology Group in Oak Ridge, Tennessee; this operation utilizes induction technology with a 20-ton melting capacity.

The effectiveness of metal decontamination by melting depends on the degree of removal of radionuclides from the metal. Thus, partitioning factors, which represent fractions of a radionuclide's mass in the melter charge that end up in the ingot, slag, and flu gas (baghouse and offgas), become an important measure of the effectiveness of decontamination. The partitioning factors are also needed for assessment of risks associated with various scenarios of operations, both to workers and also to the general public.

Key parameters affecting the partitioning rates in melt refining include the types and concentrations of radionuclides, compatibility between slags and refractory materials, melting techniques, and flux chemistries (Hertzler et al. 1993). Elements that are inherent in the input metal as alloying materials typically are not removed by the smelting process. Such elements include cobalt, iron, nickel, and carbon, which tend to be retained in the metal. With proper addition of flux, uranium and transuranic isotopes and their daughter products can be effectively removed. Separation of Tc-99 and Sr-89/90 from ingots, however, does not appear to be successful. Although partitioning data for ingots are relatively well known, the information for by-products (i.e., slag, off-gas, and baghouse dust) is less certain.

Table B.1 presents the partitioning factors for carbon steel. In this table, data have been taken from several sources (Hertzler et al. 1993; Chapuis et al. undated; Elert and Wiborgh 1992; Johnson 1993; Otis 1995; Sanford Cohen and Associates 1995; Wallo 1995; Zussman 1993). The data in Table B.1 are presented as a range (or upper bound) of findings, and representative values are selected for use in this report. The representative values are not always based on the range of findings but are also determined by considerations of consistency with values for similar elements. 
TABLE B.1 Radionuclide Partitioning Factors for Carbon Steel

\begin{tabular}{|c|c|c|c|c|c|c|c|}
\hline \multirow[b]{2}{*}{ Nuclide } & \multicolumn{2}{|c|}{ Ingot } & \multicolumn{2}{|c|}{ Slag } & \multicolumn{2}{|c|}{ Off-Gas } & \multirow[b]{2}{*}{$\begin{array}{c}\text { Baghouse } \\
\text { Dust }\end{array}$} \\
\hline & $\begin{array}{c}\text { Represen- } \\
\text { tative } \\
\text { Value }\end{array}$ & $\begin{array}{c}\text { Range or } \\
\text { Upper } \\
\text { Bound }\end{array}$ & $\begin{array}{c}\text { Represen- } \\
\text { tative } \\
\text { Value }\end{array}$ & $\begin{array}{l}\text { Range } \\
\text { or Upper } \\
\text { Bound }\end{array}$ & $\begin{array}{c}\text { Represen- } \\
\text { tative } \\
\text { Value }\end{array}$ & $\begin{array}{l}\text { Range } \\
\text { or Upper } \\
\text { Bound }\end{array}$ & \\
\hline $\mathrm{H}-3$ & 0 & 0 & 0 & 0 & 1 & 1 & 0 \\
\hline C-14 & 0.95 & $--^{a}$ & 0.05 & - & 0 & - & 0 \\
\hline$M n-54$ & 1 & $0.8-1$ & 0.01 & $0.01-0.09$ & 0.01 & $0.002-0.005$ & 0.01 \\
\hline $\mathrm{Fe}-55$ & 1 & 1 & 0.01 & 0.01 & 0.01 & 0.005 & 0.01 \\
\hline Co-57 & 1 & 0.98 & 0.01 & 0.009 & 0.01 & - & 0.01 \\
\hline Co-60 & 1 & $0.7-1$ & 0.01 & $0-0.3$ & 0.01 & $0-0.01$ & 0.01 \\
\hline $\mathrm{Ni}-63$ & 1 & $0.8-1$ & 0.01 & 0.01 & 0.01 & $0.005-0.01$ & 0.01 \\
\hline Sr-90 & 0.20 & $0.02-1$ & 0.80 & $0.8-1$ & 0 & 0.1 & 0.1 \\
\hline $\mathrm{Nb}-93 \mathrm{~m}$ & 0.02 & $0.02-1$ & 0.98 & $0.1-0.98$ & 0.01 & 0.01 & 0.01 \\
\hline $\mathrm{Nb}-94$ & 0.02 & $0.02-1$ & 0.98 & $0.1-0.98$ & 0.01 & 0.01 & 0.01 \\
\hline Tc-99 & 0.1 & $0.1-1$ & 0.1 & $0.1-1$ & 1 & 1 & 1 \\
\hline I-129 & 0 & - & 0 & - & 1 & - & 0 \\
\hline Cs-134 & 0.01 & $0-0.01$ & 0.02 & $0.02-1$ & 0.97 & $0-1$ & 0.97 \\
\hline Cs-137 & 0.01 & $0-0.01$ & 0.02 & $0.02-1$ & 0.97 & $0.03-1$ & 0.97 \\
\hline Eu-152 & 0.20 & $0-0.02$ & 0.8 & $0.8-1$ & 0 & 0.005 & 0.005 \\
\hline $\mathrm{Pb}-210^{\mathrm{b}}$ & 0.006 & - & 0 & - & 0 & - & - \\
\hline Po-210 & 0.01 & - & 0.97 & - & 0.02 & - & 0.02 \\
\hline Ra-226 & 0.01 & - & 0.97 & - & 0.02 & - & 0.02 \\
\hline $\mathrm{Ra}-228$ & 0.01 & - & 0.97 & - & 0.02 & - & 0.02 \\
\hline Th-228 & 0 & - & 1 & - & 0 & - & - \\
\hline Th-230 & 0 & - & 1 & - & 0 & - & - \\
\hline U-234 & 0.01 & - & 0.97 & - & 0.02 & - & 0.02 \\
\hline U-235 & 0.01 & - & 0.97 & - & 0.02 & - & 0.02 \\
\hline U-238 & 0.01 & - & 0.97 & - & 0.02 & - & 0.02 \\
\hline Pu-238 & 0.01 & 0.01 & 0.97 & 1 & 0.02 & $0.005-0.02$ & 0.02 \\
\hline Pu-239 & 0.01 & 0.01 & 0.97 & 1 & 0.02 & $0.005-0.02$ & 0.02 \\
\hline Am-241 & 0.01 & 0.01 & 0.97 & 1 & 0.02 & $0.005-0.02$ & 0.02 \\
\hline
\end{tabular}

a Not available.

b According to Johnson (1993), $99.4 \%$ of lead is partitioned into the refractory. 


\section{REFERENCES FOR APPENDIX B}

Chapuis, A.M., et al., undated, Exemption Limits for the Recycling of Materials from the Dismantling of Nuclear Installations, Paris, France.

Elert, M., and M. Wiborgh, 1992, Basis for Criteria for Exemption of Decommissioning Waste: Reprocessing Dust from Recycling of Steel, KEMAkta Konsult AB, report prepared for Swedish Radiation Protection Institute, June.

Hertzler, T., et al., 1993, Recycle of DOE Radioactively Contaminated Metal-A Scoping Study, Science Applications International Corporation, Idaho Falls, Idaho, Feb.

Johnson, A., 1993, personal communication from Johnson (Scientific Ecology Group, Oak Ridge, Tenn.) to S.-Y. Chen (Argonne National Laboratory, Argonne, Ill.), Oct.

Otis, M., 1995, "Comparison of Partitioning Factor Estimates," letter from Otis (Science Applications, Inc., Idaho Falls, Idaho) to R. Meck (U.S. Nuclear Regulatory Commission, Bethesda, Md.), Aug. 30.

Sanford Cohen and Associates, 1995, Analysis of Potential Recycling of Department of Energy Radioactive Scrap Metal, Draft, prepared for the U.S. Environmental Protection Agency, Office of Radiation and Indoor Air, Washington, D.C., June 26.

Wallo, A., 1995, "Partitioning Factors," letter from Wallo (U.S. Department of Energy) to S.-Y. Chen (Argonne National Laboratory, Argonne, Ill.), Sept. 12.

Zussman, R., 1993, "Processing of Austenitic Stainless Steels," in Proceedings of DOE Chartered Tritium Focus Group Conference on Recycle of Radioactively Contaminated Metals, Armco Inc. Research and Technology, Augusta, Ga., May 19-20. 